\title{
Changing Patterns in Corporate Financing and the Main Bank System in Japan
}

\author{
John Y. Campbell \\ Yasushi Hamao
}

Working Paper No. 76

\author{
John Y. Campbell \\ Woodrow Wilson School \\ Princeton University \\ and \\ Yasushi Hamao \\ Graduate School of Business \\ Columbia University
}

This paper is the final draft for the joint research project on the Japanese Main Bank System and its Relevance for Developing Market and Transforming Socialist Economies, undertaken under the auspices of the World Bank EDI Program for the Study of Japan's Development Management Experience, the Center on Japanese Economy and Business at Columbia University. This paper represents the views of the author and not those of the sponsoring institutions.

The authors thank Masahiko Aoki, Takeo Hoshi, Kensuke Hotta, Anil Kashyap, Junichi Nishiwaki, Hugh Patrick, Paul Sheard, and other participants at the workshops for useful comments and Kenichi Ichiki and Il-Pyung Park for research assistance. Hamao gratefully acknowledges support from the Batterymarch Fellowship and the Mitsubishi Trust and Banking Professorship.

\section{Working Paper Series}

Center on Japanese Economy and Business

Graduate School of Business

Columbia University

October 1993 


\section{Introduction}

For most of the postwar period, the U.S. and Japan have had polar opposite corporate financial structures. The U.S. system has featured low leverage and low monitoring of corporate management by investors, while the Japanese system has featured high leverage and high monitoring. One of the standard stories is that high leverage in Japan is justified by low bankruptcy costs. These in turn come from two important features of the main bank system: there is a high probability of bank rescues for large firms with main banks, and main banks often hold equity in firms as well as providing loans, thereby reducing conflicts of interest.

During the last 15 years, however, the two systems have begun to converge. Leverage has increased in the U.S., particularly when measured by interest expense ratios, and the increase has been concentrated in certain firms. ${ }^{1}$ In Japan, leverage has decreased across the board. In the U.S., debt-holders' interests may now be represented more effectively; Jensen (1989) argues that LBO partners are a new organizational form which can monitor corporations more effectively. In Japan, while the role of a main bank as a delegated monitor is similar to the LBO partners in the U.S., the growing use of public debt held by outsiders rather than main banks suggests the opposite trend.

This paper uses cross-sectional data to reveal more clearly the changing capital structure of Japanese corporations. We first classify firms into two groups based on their outstanding bank loans in fiscal year 1983/4. We call a firm a "main bank firm" if the largest quantity of loans to that firm is made by one of 19 major banks; we call a firm "unaffiliated" if it has no outstanding bank loans in 1983/4 or if the largest quantity of loans is made by a

\footnotetext{
'See Bernanke and Campbell (1988).
} 
smaller regional bank. This definition of a main bank firm is narrower than that proposed by Aoki, Patrick, and Sheard (1993). Almost all Japanese firms are main bank firms in Aoki, Patrick, and Sheard's sense whereas we identify numerous firms that are unaffiliated in our sense.

We next show that the trends in capital structure are very different for our two classes of firms. Main bank firms show only modest changes in capital structure, whereas unaffiliated firms have dramatically reduced their reliance on bank debt in favor of equity and equity-related debt instruments (warrant and convertible bonds). Thus unaffiliated firms have moved more decisively towards American patterns than have main bank firms.

We also study the bond issuance services provided by main banks. As described by Aoki, Patrick and Sheard (1993), these services include guaranteeing, trustee administration and underwriting. Fees generated by these activities are said to have become a significant part of revenue for large banks. We find that when main bank firms do use the bond markets, they often turn to their main banks to facilitate bond issuance. Unaffiliated firms have also used bank guarantees, but increasingly these firms have been able to issue nonguaranteed bonds.

The paper is organized as follows. The next two sections describe our data and briefly summarize the deregulation that has taken place in the corporate financial market. Section 4 examines corporate capital structure using firm-level data. We document the differences in the capital structure of firms with and without main banks by analyzing ratios such as debt to assets, bonds to total debt, and short-term debt to total debt. Section 5 presents further evidence on the role of main banks using data on individual bond issues. Section 6 
concludes.

\section{Data Description}

We concentrate on large, public corporations listed on the first and second sections of the Tokyo Stock Exchange (excluding banks, insurance companies, and securities companies) during the period 1970 to 1991 . The number of observations ranges from about 1100 companies in 1970 to 1400 in 1991 . Our data come from four separate sources.

First, we measure the market value of equity (price per share times the number of shares outstanding) using a database described in Hamao (1991). This series starts in January 1970.

Second, we take accounting data from the Nikkei NEEDS Corporate Financial Data tape (unconsolidated). This tape contains balance sheet information for all listed companies except for banks and securities companies from 1965 to 1991. Since our capitalization data start in 1970 , our observation period is from 1970 to 1991 . Delisted firms are included in the sample. The items extracted are: (1) Short-Term Borrowings (including overdraft on bills due in one year); (2) Current Position of Long-Term Debt Due within One Year; (3) Bonds and Debentures Maturing within One Year; (4) Bonds and Convertible Bonds (Debentures); and (5) Long-Term Borrowings. Since the majority of companies choose March as their fiscal year end, we take March every year as the observation point and used the most recent available information if a company adopts other than March as their fiscal year end.

The definition of the quantities are as follows:

$$
\text { Debt }=(1)+(2)+(3)+(4)+(5)
$$


Short-Term Debt $=(1)+(2)+(3)$

Bonds $=(3)+(4)$

Market Value of Equity $=$ Number of Shares Outstanding $\times$ Price; and

Total Assets $=$ Debt + Market Value of Equity

We use the book value of debt rather than trying to calculate market value; this calculation is indirect and cumbersome and has a relatively minor effect in U.S. data in the 1980 's. ${ }^{2}$

Third, we use a dataset containing information on newly issued securities for all listed companies since 1970. The original data were taken from Nikkei Corporate Action Data tapes. For each firm, we extracted information (including issuing market, yen equivalent amount raised, maturity, and names of guarantors and trustees) for new issues of straight bonds, convertible bonds, and bonds with detachable warrants from 1970 to $1991 .^{3}$ As opposed to the balance sheet figures, which are stock numbers as of the end of a fiscal year, the new issues data captures flow numbers measured at each time of the new issues. This could make a difference since a new issue of a convertible bond can be converted to equity before it is recorded as outstanding balance in the balance sheet. In order to keep the consistency in our analysis, we use stock figures when we compute ratios such as debt to asset, bond to total debt, etc. and flow figures are denoted as "new issues" to make the distinction.

The fourth dataset contains information on the main bank for each firm and is taken

${ }^{2}$ See Bernanke and Campbell (1988).

${ }^{3}$ Since the names of guarantors and trustees are only in 16-bit non-ASCII kanji characters, they were translated to corresponding numerical codes. 
from the 1987 and 1992 editions of Kigyo Keiretsu Soran. We are particularly interested in whether a firm has a main bank or not. The definition of the main bank, however, is not immediately transparent. For example, while firms with no bank loan may be considered independent of banks, most of those firms have some banks as their largest shareholders, and sometimes even directors or auditors despatched from banks. In our paper, we determine a firm's main bank in terms only of its borrowing. Thus if a firm has no bank loans, it is considered as "unaffiliated."4

For each firm, we find the bank with the largest outstanding loan balance in 1983/4. Our universe of banks includes 19 major city, trust, and long-term credit banks. ${ }^{5}$ Only these were capable of functioning as guarantors or trustees of bond issues of corporations. If the bank with the largest loan share is not one of our 19 banks, we record the firm as unaffiliated. If this bank is one of our 19 banks, we consider it to be the firm's main bank. If there is a tie (or approximate tie) between two of our banks in their loans outstanding to a firm, we record both banks as the firm's main bank.

We do not include regional banks in our universe of main banks. Our assumption

${ }^{4}$ One might argue that there are firms with no bank loans outstanding that still claim to have a main bank. We do not suggest that there are not. However, our empirical work cannot extend the definition of main bank too far. If one includes personnel exchanges and shareholdings as measures of a main bank relationship, almost all Japanese firms have main banks. The following empirical analysis indicates that there are significant differences in the behavior of firms based on our definition.

${ }^{5}$ They are Asahi Bank, Bank of Tokyo, Dai-Ichi Kangyo Bank, Daiwa Bank, Fuji Bank, Hokkaido-Takushoku Bank, Industrial Bank of Japan, Long-Term Credit Bank of Japan, Mitsubishi Bank, Mitsubishi Trust and Banking, Mitsui Trust Bank, Nippon Credit Bank, Sakura Bank, Sanwa Bank, Sumitomo Bank, Sumitomo Trust and Banking, Tokai Bank, Toyo Trust Bank, and Yasuda Trust Bank. 
here is that for the firms in our sample (large, listed firms), it is a firm's (not a lender's) decision not to have one of the large 19 banks as its main bank. Thus, we assume that a firm with the largest loan share from a regional bank has chosen to be independent of the main banking relationship with major banks. We note also that those firms with regional banks as top lenders often have a tie in the outstanding loan amount with one of the 19 large banks. We classify such a firm as having a large bank as its main bank.

In order to check the robustness of our results, we have also used two alternative ways to classify firms. First, we have used the classification scheme proposed by Aoki, Patrick, and Sheard (1993, Appendix Table 1). Their definition drops trust banks and adds regional banks. They also pay attention to stability by examining continuity of the main bank relationship over three recent years (1989-1991). Their data, however, cover only three industries (507 firms). Despite these differences, our main results are essentially unchanged when we use their approach.

Second, we have used outstanding bank loans in 1991 to classify firms. This is theoretically less satisfactory because it raises the possibility that firms' financing decisions in the 1983-91 period drive our classification. For example, suppose a firm with bank loans in 1983 contemplated reducing bank loans and issuing bonds and did so over the next 8 years. Identifying this firm as unaffiliated leads us to overstate the changes undertaken by unaffiliated firms. This is a much less serious problem for our 1983 classification scheme because the Japanese bond market was still highly regulated in 1983. In any case, despite the theoretical problem with the 1991 classification scheme we find it gives essentially the same results as our 1983 classification scheme. 
One might conjecture that our procedure for classifying firms would separate them by size; large, more established firms would tend to have closer relations with our 19 main banks and smaller firms would be less dependent on these banks. On the contrary, mean (median) capitalization in 1983 is $¥ 57.8$ billion ( $¥ 15.6$ billion) for firms with large main banks $(\mathrm{N}=$ 1067), whereas it is $¥ 65.7$ billion ( $¥ 11.9$ billion) for firms without main banks $(\mathrm{N}=314)$. There is some variation across industries in the proportion of main bank firms, as shown in Table 1, but every industry has some firms in each category.

\section{A Brief History of Postwar Japanese Corporate Financing}

The reconstruction of post-war Japan was mainly financed by bank loans. The Industrial Bank of Japan as well as major city banks played a critical role in financing industrial projects and firms. ${ }^{6}$ The corporate bond market was tightly regulated until the beginning of the 1980 's. There was a ceiling on bond interest rates which inhibited the development of the market. The issuance of bond instruments required government permission and a large amount of collateral, and only a small number of large industrial firms, regulated utilities and long-term credit banks issued corporate bonds. Firms had to satisfy various accounting conditions to establish their eligibility to issue even secured bonds. The Secured Corporate Bond Trustee Law required trustees (of collateral) to assume major responsibilities in establishing and administering pledged properties on behalf of all bondholders. These and other restrictions on corporate bond issues are discussed in more detail in Nihon Keizai Shimbun (1987) and Ramseyer (1993).

\footnotetext{
${ }^{6}$ See Packer (1993).
} 
Issuance of unsecured bonds was a relatively new phenomenon which required clearance of a different set of bond eligibility criteria introduced in 1979. These conditions were so rigid that only Matsushita Electric and Toyota Motors were qualified to issue unsecured convertible or straight bonds in 1979. The criteria for both secured and unsecured bonds were relaxed gradually in the 1980 's, and by 1989 approximately 300 firms were eligible to issue unsecured straight or warrant-attached bond issues, and 500 firms were eligible to issue unsecured convertible bonds. ${ }^{7}$ In 1990, eligibility criteria based on accounting information were replaced by a single bond rating criterion. The quantity of straight bonds actually issued, however, did not grow as fast as the quantity of equity-related bonds perhaps because of the overwhelming appeal of warrant and convertible bonds during the stock price "boom" period of the late 1980's.

The removal of restrictions on overseas financial activities by the amendment of the Foreign Exchange Law of 1980 enabled firms to issue bonds in overseas markets. The Ministry of Finance used essentially the same eligibility criteria for overseas bond issues as for domestic bond issues, so that there was virtually no case of a Euro issue of a corporate bond by a domestically ineligible firm. Euro issues did, however, offer several advantages:

(1) Even after eliminating exchange risk with a currency swap, it was often possible to realize a lower yen interest rate for dollar-denominated issues and the domestic issue of foreign currency denominated bonds was not permitted; (2) Exporting firms were able to match dollar-denominated liabilities with dollar-denominated accounts receivable so as to reduce or

${ }^{7}$ Hoshi, Kashyap and Scharfstein (1993) summarize three changes in the eligibility conditions for secured convertible bonds in the 1980's. 
eliminate exposure to exchange risk; (3) By contrast with the domestic market where collateral is normally required, the Euro market did not require collateral, and therefore (4) Bond trustee administration fees for Euro issues were much lower than for domestic issues.

To take advantage of the stock market boom of the late 1980's, many firms issued equity-related bond instruments. These too were issued mainly in the Euro market. In 1981, bonds with equity warrants (originally undetachable) were legalized, and in 1986 the detached warrant components were permitted to be brought back to be traded in Japan. Warrants typically had strike prices $20-25 \%$ above the stock price at the time of issue. Convertible bonds were also popular; the conversion price for such bonds was mostly set to be only 5$10 \%$ above the stock price at the time of issue.

Although we do not have detailed data on the buyers of corporate bonds, Nihon Keizai Shimbun Sha (1987) provides a breakdown of investors for the new issues in 1985. The largest share was purchased by individuals (49.1\%) and financial institutions bought $28.5 \%$.

Table 2 shows new issue quantities for various types of bonds in both domestic and overseas markets during the periods $1984-87$ and $1988-91$. We note that there are large increases in convertible and warrant attached bond issues. Warrant attached bonds became especially popular in the overseas market. Each category is further divided into bank guaranteed and non-guaranteed issues. ${ }^{8}$ We will discuss this point in more detail in the next two sections.

\footnotetext{
${ }^{8}$ Convertible bonds were rarely guaranteed, perhaps because the option of conversion to equity makes the amount to be guaranteed uncertain ex ante.
} 


\section{Trends in Capital Structure and the Main Bank Relation}

In this section, we compute several measures of corporate leverage and relate these to the issuers' relationship with their main banks.

Figure 1 shows the ratio of debt to total assets for the full sample, computed as $\Sigma($ Debt $) / \Sigma$ (Asset) where the summation is taken across firms. This aggregate ratio can be thought as the value-weighted average for the sample. The aggregate debt to asset ratio has declined from 0.6 to 0.25 over the sample period, increasing slightly in the last two years because of the decline in stock prices.

There is an important caveat. Table 2 shows a large increase in equity-related bond issues in the late 1980's. Taking the whole amount raised by those instruments as debt overstates total debt since warrant and convertible bonds contain equity components. For example, the present value of a warrant attached bond (the amount raised by the issuer) is the sum of the present value of the warrant component and that of the coupon bond. Many warrant bonds were issued at an effective yen interest rate close to zero (Chang 1992); that is, the promise to pay 100 yen 5 years in the future, together with the attached warrant, fetched 100 yen at issue. With a Japanese government 5 -year interest rate of $5 \%$, a promise to pay 100 yen 5 years in the future should be worth no more than 78 yen today, suggesting that only $78 \%$ of the value of the warrant bond is straight debt. We do not pursue this further, but simply take care to distinguish warrant and convertible bonds from straight bonds and bank loans.

We next divide the sample into firms with and without main banks. We present the comparison using boxplots (Figure 2), which show the time series of the median and the 
quartiles around the median. Isolated bars represent outliers. These plots show that within each group, firms have become more homogeneous in their debt to asset ratios, especially during the late 1980 's. However the two groups have diverged in that unaffiliated firms show a stronger decline in their debt to asset ratios.

A second measure of corporate capital structure is the ratio of bonds to total debt. In the face of deregulation corporations have tended to shift their source of debt financing from bank loans to bond issues. The choice between bonds and bank loans is discussed in detail by Hoshi, Kashyap and Scharfstein (1993), who find that profitability (as measured by Tobin's q) is positively related to the ratio of bonds to total debt. Here we focus instead on the relation between main bank affiliation and bond issuance.

In aggregate, bonds have become increasingly important. However, treating all bond issues as "public debt" is misleading since some bonds are guaranteed by banks. Bank guarantees, which make bonds virtually a securitized version of bank loans, apply to some Euro issues of straight bonds and warrant attached bonds. The issuing firms benefit from lower interest rates when their bonds are guaranteed by banks with a high credit rating, while the banks get fees for their guarantees. Figure 3 shows two measures of the bond to total debt ratio; the first one uses a conventional definition of bonds without distinguishing the issues that are guaranteed by banks, and the second one excludes bank guaranteed issues. ${ }^{9}$ There is a remarkable growth in the share of bonds in total debt, but the bank guarantee correction proves to be a sizeable 5 percentage points in 1991 .

\footnotetext{
${ }^{9}$ The "conventional" one is essentially the same as Figure 2a of Hoshi, Kashyap and Scharfstein (1993).
} 
We again divide the sample into firms with and without large main banks, excluding bank guaranteed issues (Figure 4-1). The difference between the two groups is striking. Although some firms with main bank alliances increased their use of bonds, the median bond to debt ratio remains very close to zero. On the other hand, firms without main banks increased their use of bonds dramatically after 1985 and the median bond to debt ratio for this group is close to $20 \%$ in 1991 . We also note that the distribution of the ratio is much more dispersed for the unaffiliated firms, indicating greater variation of financing strategies among these firms.

When we repeat the same exercise including bank guaranteed issues in bonds, the difference between main bank and unaffiliated firms becomes even larger (Figure 4-2). This suggests that unaffiliated firms were willing to use bank guarantees as they moved aggressively to exploit newly available bond instruments. Qualified unaffiliated firms did not seek the traditional main bank relationship of increasing bank loans, but rather obtained bank guarantees.

Bank loans from city banks are typically short-term whereas bond issues (straight, convertible or warrant attached) have maturities more than one year. Thus the ratio of shortterm (less than one year) debt to total debt can also reveal a shift between bank loan and bond issues. Figure 5 displays the aggregate series, and Figure 6 shows the breakdown between main bank and unaffiliated firms. Just as one would expect from looking at the bond to total debt ratio, the short-term debt ratios of the two types of firms diverge around 1985, with unaffiliated firms using substantially less short-term debt. The yield spread between Japanese 5-6 year government bond and the short rate narrowed over 1980-85 and the yield 
curve stayed relatively flat in $1985-90 .^{10}$ Furthermore, as mentioned earlier, issuing equityrelated bonds in the Euro market gave issuing firms access to even cheaper funds. Unaffiliated firms appear to have reacted more swiftly to this opportunity than main bank firms. In part this may have been because firms affiliated with main banks were able to roll over short-term borrowing quite readily, thereby using them for longer-term finance purposes.

Finally, Figures 7-8 show that for unaffiliated firms, equity-related bonds substituted for short-term bank loans in the late 1980's. Main bank firms made considerably less use of these instruments. Again, it should be noted that the distribution of the ratios for unaffiliated firms are much more dispersed, indicating that the change did not occur uniformly among unaffiliated firms.

To highlight these findings, we report some summary statistics in Table 3 . We compute the ratios of warrant, convertible, and straight bonds to total debt. Here the numerators are cumulative new issues of those bonds during 1988-1991 and the denominator is total debt in 1988. The sample is then divided into groups above and below the median for these ratios. For each group we compute the means of capitalization, the debt to asset ratio, the loan to debt ratio, and the score of $(1=$ main bank firm, $0=$ unaffiliated firm $)$. There is a clear distinction between the equity-related bonds and straight bonds. For convertible and warrant bonds, the firms above median are smaller in capitalization, lower in existing debt to asset and loan to total debt ratios, and weaker in main bank relations than the firms below median. For straight bond to total debt ratio, larger firms tend to issue more, but existing debt to asset and loan to total loan ratios as well as main bank relations do not seem to be

\footnotetext{
${ }^{10}$ See Campbell and Hamao (1993).
} 
strongly related to the firms propensity to issue straight bonds.

There is an apparent contrast between these results and those of Hoshi, Kashyap and Scharfstein (1993). Hoshi et al. investigate the effect of industrial groups (keiretsu) and present weak evidence that non-group firms with attractive investment opportunities rely more heavily on bank financing. These findings are not in fact contradictory because the distinction between group and non-group firms is not the same as the distinction between main bank and unaffiliated firms under the definition used here. Unaffiliated firms may belong to a group (e.g., Shiseido, which is a member of Dai-Ichi Kangyo Bank group, but has no bank loan) while non-group firms may still have main banks (e.g., many family-controlled businesses). In fact, of the 52 firms Hoshi et al. classify as group firms, 44 (85\%) are main bank firms in our sense; of the 60 firms Hoshi et al. classify as non-group firms, 46 (77\%) are main bank firms. Thus there is only a weak correlation between the two classification systems.

The study of Hoshi et al. is relevant in another way. One possible objection to our analysis is that we ignore the bond eligibility conditions that restricted companies' ability to issue bonds during much of our sample period. It could be argued that unaffiliated firms are simply those which meet the bond eligibility conditions, and this is why they have behaved differently from main bank firms. Hoshi et al. consider 112 firms that were continuously eligible to issue convertible bonds from 1982 to 1989 . By discarding all firms which did not continuously satisfy the bond eligibility conditions, Hoshi et al. eliminate any spurious effects of bond eligibility. The cost of this strategy is of course that they work with a much smaller sample of firms. 
We reproduced our analysis represented in Figures 2, 4 and 6 for the 112 firms considered by Hoshi et al. ${ }^{11}$ The 90 main bank firms in this sample shifted their financing more toward bonds and equity-related instruments than did the larger group of main bank firms considered earlier; but it is nonetheless the case that the 22 unaffiliated firms moved towards these financing strategies even more decisively than the 90 main bank firms. Thus the distinction between main bank firms and unaffiliated firms appears to be important even when one controls for bond eligibility.

Putting these results together, we reach the following conclusions about changing corporate finance patterns in Japan. Firms with main bank relations rely more heavily on debt than unaffiliated firms; in addition these firms shift less toward newly deregulated equity-related bond instruments and stay with traditional bank loans. Thus the major changes in corporate finance have occurred among unaffiliated firms, not main bank firms.

\section{Analysis of Individual Bond Data: Bank Guarantees}

In this section, we analyze data on individual bond issues and investigate the relations between bond issuers and their main banks. Of particular interest are the cases where banks become guarantors or trustees of bond issues. ${ }^{12}$ As discussed earlier, bank guarantees on straight and warrant attached bonds can be considered as an extended form of bank loans. Facing financial deregulation (including the gradual removal of the Japanese version of Glass-

\footnotetext{
${ }^{11}$ We thank Takeo Hoshi for providing the data to us. The results in figure form are available upon request from the authors.

${ }^{12}$ See Aoki, Patrick and Sheard (1993).
} 
Steagall restrictions) and increasing demand for bond issuance, it is likely that banks have intended to become major players in the securities industry by building up their corporate bond issuing related business. Bank guarantees were especially necessary in the earlier stages of the introduction of Euro bonds when most issuers were unfamiliar to foreign investors. The knowledge of issuing firms obtained through traditional monitoring enabled main banks to screen bond issues for guaranteeing. The market for bond guaranteeing was said to have been as competitive as the loan market, and several banks offered guarantee fees as low as 0.1 (usually $0.15-0.2) \% .^{13}$

Another bond issuance service is to provide trustee administration. ${ }^{14}$ The responsibilities of a trustee bank often go beyond straightforward administration especially in the case of secured bonds. Traditionally, domestic corporate bonds have been collateralized by specified plant and equipment. Trustee banks are then responsible for examining the collateral and securing the payments on behalf of general bondholders. In fact, from 1945 to 1990 there were eleven corporate bond defaults. Ten of these firms went through the legal process of corporate reorganization, nine out of those ten issues had collateral (or a bank guarantee), and all of these issues were bought back by trustee banks even though they were

\footnotetext{
${ }^{13}$ Guaranteed bonds are carried on the book sas a risk asset. BIS (Bank for International Settlement) regulation on capital adequacy, however, was not a binding restriction especially for our first subperiod (1984-87), since the condition was established in 1988 to be accomplished by 1993, and the Japanese stock market stayed at a high level until the end of 1989.

${ }^{14}$ Underwriting of Eurobonds is also an important business for main banks through their overseas subsidiaries. Unfortunately, we are unable to extend our analysis to this since our database does not provide names of underwriters if they are overseas subsidiaries of Japanese banks or securities houses.
} 
not legally obligated to do so. Thus the role of a trustee bank is similar to that of a guaranteeing bank. We document the relations between bond guarantors (and trustees) and the main bank alliance by examining six large city banks and the Industrial Bank of Japan.

First, from Table 2 we note some changes in bank guarantees in straight and warrant bond issues between the $1984-87$ and $1988-91$ periods. For straight bonds, the total amount of new issues did not grow substantially, but the guaranteed portion of overseas issues decreased from $38 \%$ to $10 \%$. For warrant bonds there was dramatic growth of the total amount issued; the percentage guaranteed for overseas issues dropped from $77 \%$ to $34 \%$, although the quantity guaranteed increased from $¥ 2.6$ trillion to $¥ 6.2$ trillion.

We sort firms by the proportion of guarantees in new issues and take summary statistics for them. For each firm in the 1984-87 and 1988-91 periods, cumulative total and guaranteed amounts of new issues of warrant and straight bonds are computed, and the ratio of guaranteed to total are calculated. The distributions of the ratios are in all cases bimodal with $0 \%$ and $100 \%$ most frequently observed. Thus the samples of in the two time periods are divided into two; one with all new issues guaranteed and the other with none guaranteed. For these two categories the mean of capitalization, the debt to asset ratio, the loan to debt ratio, and the main bank "score" (as of 1987 and 1991 respectively) are computed. Table 4, Panel A shows the results. In all cases, capitalization again shows a clear distinction between the two groups. Firms that issued guaranteed bonds are smaller than those that were able to issue bonds without guarantees. The loan to total debt ratio also exhibits a consistent pattern. A higher loan ratio is observed for the firms that have a higher guarantee ratio. There is no clear pattern with respect to main bank relations. 
Given the significant change in the proportion of guaranteed warrant bond issues over the two subperiods, it is interesting to examine what types of firms have moved away from bank guarantees when they issue new bond instruments. We take the difference of the guarantee ratio between the two subperiods and again calculate the attributes of the firms that increased or decreased their reliance on bank guarantees. The results are tabulated in Table 4, Panel B, which show that the firms with decreased dependence are larger in size and weaker in their main bank alliances.

This point can be examined more directly by inspecting individual bond issue data. We ask two questions, one from the viewpoint of the main banks, the other from the viewpoint of the issuing firms. That is: (1) Out of the bond issues guaranteed by bank A, what proportio is for firms that have bank A as their main bank? (2) Out of the guaranteed bonds issued by a firm with bank $\mathrm{A}$ as its main bank, what proportion is guaranteed by bank A? These questions can be asked not only for guarantees, but also for trustee administration. We investigate this point for the Industrial Bank of Japan and six major city banks (Dai-Ichi Kangyo, Fuji, Mitsubishi, Sakura, Sanwa, and Sumitomo).

Table 5 summarizes the results. In general, the correlation between the main bank and the guarantor/trustee bank is high for major keiretsu banks. Except in a few cases, the bonds banks guarantee are more than $60 \%$ for their main bank clients, and firms also turn more than $70 \%$ of the time to their main bank for bond guarantees. We can confirm similar strong correlations for trustee banks as well. ${ }^{15}$

\footnotetext{
${ }^{15}$ It is customary to have three trustee banks for each issue of bonds. Since the first-listed trustee bank (shujutaku ginko) plays a major role in trustee administration, we take only the first bank as the trustee.
} 
Another point to note is that for guaranteed or trusteed issues, the percentages described above do not change very much between the two subperiods. In other words the guarantee or trustee role of the main bank alliance is not disturbed by the secular movement toward more non-guaranteed issues. Banks remain likely to guarantee the bonds issued by their main bank clients and once a bond is guaranteed, it is likely to be done by the issuer's main bank, rather than other banks.

To complement this point, we also computed the ratio of bank guarantees for unaffiliated firms in the same two subperiods. For unaffiliated firms, the ratios of guaranteed bonds to total bond issues have declined sharply, from $66 \%$ to $10 \%$ for straight bonds, and from $72 \%$ to $20 \%$ for warrant attached bonds. These figures indicate a much more distinctive decline in the proportion of bank guarantees compared to the general data for the whole sample shown in Table 2, suggesting more willingness for the unaffiliated firms to cut any dependence on banks.

In summary, there is a growing tendency not to utilize bond issue guarantees, but the decision to have a guarantee or not seems to be made before the decision about which bank to use. Firms with main banks tend not to disturb their main bank relations by breaking the tie with their banks when a bank guarantee is needed. Rather, most qualified firms have chosen an altogether different route and issued bonds without any bank guarantee at all.

\section{Summary and Conclusions}

We have argued that the main bank system continues to have an important role in Japanese corporate finance. There appear to be two types of Japanese firms with rather 
differentbehavior: Firms with main banks continue to rely heavily on bank debt and guaranteed bond issues, while during the last 10 years unaffiliated firms have turned to nonguaranteed bond issues and innovative debt instruments such as warrant and convertible bonds. The difference between the two groups of firms is apparent even when we confine our attention to a smaller sample of the 112 firms (used by Hoshi, Kashyap and Scharfstein (1993)) that were eligible to issue bonds over the whole period 1982 to 1989.

In the U.S. and U.K. it is often argued that the future of commercial banking lies with fee-generating services, over-the-counter derivative products, and sophisticated risk management, as opposed to the traditional provision of bank loans. To a limited extent this trend is apparent in Japan, as large banks have substituted bond guarantees for some direct lending. Nonetheless main banks continue to have an important role in traditional lending to those firms affiliated with them. 


\section{References}

Aoki, Masahiko, Hugh Patrick and Paul Sheard, 1993, "The Japanese Main Bank System: An Introductory Overview," Chapter 1 of this volume.

Bernanke, Ben S. and John Y. Campbell, 1988, "Is there A Corporate Debt Crisis?" Brookings Papers on Economic Activity 1:83-125.

Campbell, John Y. and Yasushi Hamao, 1993, "The Interest Rate Process and the Term Structure of Interest Rates," in Kenneth J. Singleton (ed.) Jopanese Monetary Policy, Chicago: University of Chicago Press.

Chang, P.H. Kevin, 1992, "Pricing Inefficiencies in Japanese Equity Warrant Markets," Working Paper, New York University.

Hoshi, Takeo, Anil Kashyap, and David Scharfstein, 1993, "The Choice Between Public and Private Debt: An Analysis of Post-Deregulation Corporate Financing in Japan," Working Paper, University of California, San Diego.

Hamao, Yasushi, 1990, "A Standard Data Base for the Analysis of the Japanese Security Markets," Journal of Business, 64, 87-102.

Jensen, Michael C., 1989, "Eclipse of the Public Corporation," Harvard Business Review 89:61-74.

Nihon Keizai Shimbun Sha (ed.), 1987, Koshasai Hakko Shijo (Bond Primary Markets), Tokyo.

Packer, Frank, 1993, "The Role of Long-Term Credit Banks within the Japanese Main Bank System," Chapter 5 of this volume.

Ramseyer, J. Mark, "Explicit Reasons for Implicit Contracts: The Legal Logic to the Japanese Main Bank System," Chapter ?? of this volume.

Toyo Keizai Shimpo Sha (ed.), 1987, Kigyo Keiretsu Soran (Almanac of Firm Affiliations) 1987, Tokyo.

Toyo Keizai Shimpo Sha (ed.), 1992, Kigyo Keiretsu Soran (Almanac of Firm Affiliations) 1992, Tokyo. 
Table 1.

Proportion of Firms with Main Bank by Industry

$\begin{array}{ll}\text { Fishing, Mining } & 87 \% \\ \text { Construction } & 83 \\ \text { Food } & 70 \\ \text { Textile } & 79 \\ \text { Paper, Pulp } & 83 \\ \text { Pharmaceutical } & 57 \\ \text { Oil, Rubber } & 93 \\ \text { Ceramics, Glass } & 82 \\ \text { Steel } & 88 \\ \text { Non-Ferro Metal } & 79 \\ \text { Machinery } & 66 \\ \text { Electric } & 64 \\ \text { Shipbuilding } & 100 \\ \text { Auto } & 72 \\ \text { Precision Machinery } & 72 \\ \text { Printing, Office Machine } & 88 \\ \text { Trading } & 80 \\ \text { Retail } & 94 \\ \text { Non-Bank Financial } & 88 \\ \text { Real Estate } & 90 \\ \text { Land Transport } & 94 \\ \text { Air, Sea Transport } & 97 \\ \text { Warehouse, Communication } & 83 \\ \text { Electricity, Gas } & 87 \\ \text { Service } & 64 \\ & \\ \text { Mean of full sample } & 77 \%\end{array}$


Table 2.

Amount of Newly Issued Bonds

(in Billion Yen)

Panel A. Straight Bonds

\begin{tabular}{||c|c||c|c||}
\hline \multicolumn{1}{||c|}{$\begin{array}{c}\text { Issuing } \\
\text { Market }\end{array}$} & $\begin{array}{c}\text { Amount Issued } \\
\text { (\% of total) }\end{array}$ & $\begin{array}{c}\text { Amount Guaranteed } \\
\text { by Banks }\end{array}$ & $\begin{array}{c}\text { Percentage of Bank } \\
\text { Guarantees }\end{array}$ \\
\hline Japan & $\begin{array}{l}3,142.5 \\
(43.0 \%)\end{array}$ & 0.0 & $0.0 \%$ \\
\hline Overseas & $\begin{array}{l}4,202.4 \\
(57.0 \%)\end{array}$ & $1,607.0$ & $38.2 \%$ \\
\hline \hline Total & $\begin{array}{l}7,344.9 \\
(100 \%)\end{array}$ & $1,607.0$ & $21.9 \%$ \\
\hline Japan & $\begin{array}{l}5,119.0 \\
(60.9 \%)\end{array}$ & $1988-1991$ & $0.1 \%$ \\
\hline Overseas & $\begin{array}{l}3,282.4 \\
(39.1 \%)\end{array}$ & 3.0 & $10.3 \%$ \\
\hline \hline Total & $\begin{array}{l}8,401.4 \\
(100 \%)\end{array}$ & 339.0 & $4.1 \%$ \\
\hline \hline
\end{tabular}


Table 2.

Panel B. Convertible Bonds

\begin{tabular}{||c|c||c|c||}
\hline \multicolumn{1}{||c|}{$\begin{array}{c}\text { Issuing } \\
\text { Market }\end{array}$} & $\begin{array}{c}\text { Amount Issued } \\
\text { (\% of total) }\end{array}$ & $\begin{array}{c}\text { Amount Guaranteed } \\
\text { by Banks }\end{array}$ & $\begin{array}{c}\text { Percentage of Bank } \\
\text { Guarantees }\end{array}$ \\
\hline Japan & $\begin{array}{c}6,929.5 \\
(67.7 \%)\end{array}$ & 0.0 & $0.0 \%$ \\
\hline Overseas & $\begin{array}{c}3,309.4 \\
(32.3 \%)\end{array}$ & 21.3 & $0.6 \%$ \\
\hline \hline Total & $\begin{array}{c}10,238.9 \\
(100 \%)\end{array}$ & 21.3 & $0.2 \%$ \\
\hline Japan & $\begin{array}{l}16,139.0 \\
(88.1 \%)\end{array}$ & 0.0 & $0.0 \%$ \\
\hline Overseas & $\begin{array}{l}2,188.3 \\
(11.9 \%)\end{array}$ & 2.8 & $0.1 \%$ \\
\hline \hline Total & $\begin{array}{l}18,327.3 \\
(100 \%)\end{array}$ & 2.8 & $0.02 \%$ \\
\hline \hline
\end{tabular}


Table 2.

Panel C. Warrant Attached Bonds

\begin{tabular}{||c|c||c|c||}
\hline $\begin{array}{c}\text { Issuing } \\
\text { Market }\end{array}$ & $\begin{array}{c}\text { Amount Issued } \\
\text { (\% of total) }\end{array}$ & $\begin{array}{c}\text { Amount Guaranteed } \\
\text { by Banks }\end{array}$ & $\begin{array}{c}\text { Percentage of Bank } \\
\text { Guarantees }\end{array}$ \\
\hline \multicolumn{4}{||c|}{$1984-1987$} \\
\hline Japan & $\begin{array}{c}142.0 \\
(4.0 \%)\end{array}$ & 0.0 & $0.0 \%$ \\
\hline Overseas & $\begin{array}{c}3,452.2 \\
(96.0 \%)\end{array}$ & $2,662.4$ & $77.1 \%$ \\
\hline \hline Total & $\begin{array}{l}3,594.2 \\
(100 \%)\end{array}$ & $2,662.4$ & $74.1 \%$ \\
\hline Japan & $\begin{array}{l}1,180.0 \\
(6.1 \%)\end{array}$ & $1988-1991$ & $0.0 \%$ \\
\hline Overseas & $\begin{array}{l}18,269.8 \\
(93.9 \%)\end{array}$ & $6,159.1$ & $33.7 \%$ \\
\hline \hline Total & $\begin{array}{l}19,449.8 \\
(100 \%)\end{array}$ & $6,159.1$ & $31.7 \%$ \\
\hline
\end{tabular}

For the universe of 1471 firms listed on the Tokyo Stock Exchange, excluding banks, insurance and securities firms. 
Table 3.

New Bond Issues and Firm Characteristics

\begin{tabular}{|c|c|c|c|c|c|}
\hline & $\begin{array}{l}\text { No. } \\
\text { of } \\
\text { firms }\end{array}$ & $\begin{array}{l}\text { mean cap } \\
\text { (billion yen) }\end{array}$ & $\begin{array}{l}\text { mean } \\
\text { Debt/Asset } \\
\text { ratio }\end{array}$ & $\begin{array}{l}\text { mean } \\
\text { Loan/Debt } \\
\text { ratio }\end{array}$ & $\begin{array}{l}\text { mean } \mathrm{MB} \\
\text { score }\end{array}$ \\
\hline CB/DEBT & & & & & \\
\hline Above median & 277 & 186.97 & 0.153 & 0.647 & 0.635 \\
\hline Below median & 277 & 336.99 & 0.358 & 0.768 & 0.866 \\
\hline WB/DEBT & & & & & \\
\hline Above median & 237 & 176.17 & 0.193 & 0.672 & 0.684 \\
\hline Below median & 237 & 351.98 & 0.376 & 0.776 & 0.886 \\
\hline SB/DEBT & & & & & \\
\hline Above median & 130 & 615.18 & 0.229 & 0.724 & 0.846 \\
\hline Below median & 130 & 266.60 & 0.391 & 0.813 & 0.885 \\
\hline
\end{tabular}

CB/DEBT, WB/DEBT, SB/DEBT ratios are computed using the following definitions. CB (WB, SB) = amount of new convertible (warrant attached, straight) bond issues during 19881991; $\mathrm{DEBT}=$ total debt in 1988. For firms with non-zero ratios, summary statistics are computed for above and below median of those ratios. Means are taken cross-sectionally. "Loan" in Loan/Debt ratio includes bank-guaranteed bonds. "MB score" is computed using (1 $=$ have large city, trust or long-term credit bank as main bank, $0=$ do not). 
Table 4.

Panel A. Bank Guaranteed Bond Ratio and Firm Characteristics

\begin{tabular}{|c|c|c|c|c|c|}
\hline & $\begin{array}{l}\text { No. } \\
\text { of } \\
\text { firms }\end{array}$ & $\begin{array}{l}\text { mean cap } \\
\text { (billion yen) }\end{array}$ & $\begin{array}{l}\text { mean } \\
\text { Debt/Asset } \\
\text { ratio }\end{array}$ & $\begin{array}{l}\text { mean } \\
\text { Loan/Debt } \\
\text { ratio }\end{array}$ & $\begin{array}{l}\text { mean MB } \\
\text { score }\end{array}$ \\
\hline 1987 & & & & & \\
\hline WB $100 \%$ guaranteed & 215 & 160.72 & 0.309 & 0.839 & 0.850 \\
\hline WB $0 \%$ guaranteed & 30 & 798.67 & 0.276 & 0.512 & 0.833 \\
\hline SB 100 guaranteed & 102 & 203.00 & 0.396 & 0.851 & 0.870 \\
\hline SB $0 \%$ guaranteed & 95 & 101.22 & 0.328 & 0.650 & 0.882 \\
\hline 1991 & & & & & \\
\hline WB $100 \%$ guaranteed & 280 & 133.61 & 0.268 & 0.896 & 0.831 \\
\hline WB $0 \%$ guaranteed & 165 & 745.11 & 0.244 & 0.351 & 0.761 \\
\hline SB $100 \%$ guaranteed & 32 & 159.63 & 0.282 & 0.874 & 0.864 \\
\hline SB $0 \%$ guaranteed & 226 & 419.78 & 0.280 & 0.610 & 0.841 \\
\hline
\end{tabular}

Ratios of guaranteed amount to total new issue for straight and warrant attached bonds are computed for each firm in two periods (1984-87 and 1988-91). Then statistics as of 1987 and 1991 are obtained for firms that have $100 \%$ or $0 \%$ guaranteed bonds. Means are taken crosssectionally. "Loan" in Loan/Debt ratio includes bank-guaranteed bonds. "MB score" is computed using ( $1=$ have large city, trust or long-term credit bank as main bank, $0=$ do not). 
Table 4.

Panel B. Change in Bond Guarantees and Firm Characteristics

\begin{tabular}{||l|l|l|l|l|l||}
\hline & $\begin{array}{l}\text { No. of } \\
\text { firms }\end{array}$ & $\begin{array}{l}\text { mean cap } \\
\text { (billion } \\
\text { yen) }\end{array}$ & $\begin{array}{l}\text { mean } \\
\text { Debt/Asset } \\
\text { ratio }\end{array}$ & $\begin{array}{l}\text { mean } \\
\text { Loan/Debt } \\
\text { ratio }\end{array}$ & $\begin{array}{l}\text { mean MB } \\
\text { score }\end{array}$ \\
\hline \hline SB guarantee ratio & & & & & \\
Increased & 5 & 155.11 & 0.239 & 0.781 & 1.000 \\
Decreased & 44 & 401.51 & 0.420 & 0.820 & 0.831 \\
\hline WB guarantee ratio & & & & & \\
Increased & 9 & 143.60 & 0.363 & 0.867 & 0.889 \\
Decreased & 77 & 352.45 & 0.298 & 0.788 & 0.793 \\
\hline
\end{tabular}

Summary statistics are computed for the firms that changed from $100 \%$ guaranteed to $0 \%$ guaranteed (and vice versa) between two periods (1984-87 and 1988-91). Means are taken crosssectionally. "Loan" in Loan/Debt ratio includes bank-guaranteed bonds. "MB score" is computed using $(1=$ have large city, trust or long-term credit bank as main bank, $0=$ do not $)$. 
Table 5.

Main Bank and Bond Issue-Related Services

Panel A. Bond Guarantees

\begin{tabular}{||l||c|c||c|c||}
\hline \multicolumn{1}{|c|}{} & \multicolumn{2}{c||}{ Straight Bonds } & \multicolumn{2}{c||}{$\begin{array}{c}\text { Warrant Attached } \\
\text { Bonds }\end{array}$} \\
\cline { 2 - 5 } & $1984-87$ & $1988-91$ & $1984-87$ & $1988-91$ \\
\hline \hline Industrial Bank of Japan & $58 \%$ & $46 \%$ & $88 \%$ & $72 \%$ \\
\hline Dai-Ichi Kangyo Bank & 89 & 59 & 69 & 76 \\
\hline Sakura Bank & 43 & 64 & 69 & 85 \\
\hline Mitsubishi Bank & 51 & 60 & 60 & 71 \\
\hline Fuji Bank & 50 & 59 & 72 & 72 \\
\hline Sumitomo Bank & 68 & 70 & 60 & 82 \\
\hline Sanwa Bank & 78 & 42 & 72 & 75 \\
\hline
\end{tabular}

This table gives the answer to the question: Out of the bond issues guaranteed by bank A, what proportion (in amount) is for firms that have bank A as their main bank?

\begin{tabular}{||l||c|c||c|c||}
\hline \multicolumn{1}{|c||}{} & \multicolumn{2}{c||}{ Straight Bonds } & \multicolumn{2}{c||}{$\begin{array}{c}\text { Warrant Attached } \\
\text { Bonds }\end{array}$} \\
\cline { 2 - 5 } & $1984-87$ & $1988-91$ & $1984-87$ & $1988-91$ \\
\hline \hline Industrial Bank of Japan & $61 \%$ & $100 \%$ & $79 \%$ & $79 \%$ \\
\hline Dai-Ichi Kangyo Bank & 71 & 96 & 72 & 100 \\
\hline Sakura Bank & 52 & 100 & 83 & 98 \\
\hline Mitsubishi Bank & 77 & 71 & 99 & 97 \\
\hline Fuji Bank & 97 & 71 & 82 & 70 \\
\hline Sumitomo Bank & 74 & 61 & 82 & 94 \\
\hline Sanwa Bank & 78 & 100 & 73 & 70 \\
\hline
\end{tabular}

This table gives the answer to the question: Out of the guaranteed bonds issued by a firm having bank $\mathrm{A}$ as its main bank, what proportion (in amount) is guaranteed by bank $\mathrm{A}$ ? 
Table 5.

Panel B. Bond Trustee Administration

\begin{tabular}{|c|c|c|c|c|c|c|c|c|c|c|c|c|}
\hline & \multicolumn{5}{|c|}{ Straight Bonds } & \multicolumn{5}{|c|}{ Convertible Bonds } & \multicolumn{2}{|c|}{$\begin{array}{c}\text { Warrant Attached } \\
\text { Bonds }\end{array}$} \\
\hline & $70-75$ & $76-79$ & $80-83$ & $84-87$ & $88-91$ & $70-75$ & $76-79$ & $80-83$ & $84-87$ & $88-91$ & $84-87$ & $88-91$ \\
\hline $\begin{array}{l}\text { Industrial } \\
\text { Bank of } \\
\text { Japan }\end{array}$ & $93 \%$ & $94 \%$ & $96 \%$ & $96 \%$ & $96 \%$ & $65 \%$ & $65 \%$ & $71 \%$ & $71 \%$ & $73 \%$ & $58 \%$ & $77 \%$ \\
\hline $\begin{array}{l}\text { Dai-Ichi } \\
\text { Kangyo Bank }\end{array}$ & 98 & 91 & 98 & 6 & 0 & 88 & 100 & 87 & 73 & 83 & 100 & 100 \\
\hline Sakura Bank & 96 & 97 & 98 & 100 & 100 & 72 & 49 & 42 & 50 & 47 & 100 & 100 \\
\hline $\begin{array}{l}\text { Mitsubishi } \\
\text { Bank }\end{array}$ & 75 & 77 & 82 & 51 & 100 & 66 & 63 & 71 & 57 & 63 & 58 & 25 \\
\hline Fuji Bank & 40 & 26 & 45 & 100 & 100 & 61 & 73 & 47 & 65 & 60 & NA & 75 \\
\hline $\begin{array}{l}\text { Sumitomo } \\
\text { Bank }\end{array}$ & 73 & 79 & 71 & 100 & NA & 77 & 69 & 56 & 62 & 53 & NA & 100 \\
\hline Sanwa Bank & 92 & 94 & 98 & 97 & NA & 81 & 96 & 70 & 49 & 76 & 100 & 61 \\
\hline
\end{tabular}

This table gives the answer to the question: Out of the bond issues trusteed by bank A (as the first trustee), what proportion (in amount) is for firms that have bank $\mathrm{A}$ as their main bank? NA indicates that the first trusteed amount is zero. 
Table 5 .

Panel B. Bond Trustee Administration (continued)

\begin{tabular}{|c|c|c|c|c|c|c|c|c|c|c|c|c|}
\hline & \multicolumn{5}{|c|}{ Straight Bonds } & \multicolumn{5}{|c|}{ Convertible Bonds } & \multicolumn{2}{|c|}{$\begin{array}{c}\text { Warrant Attached } \\
\text { Bonds }\end{array}$} \\
\hline & $70-75$ & $76-79$ & $80-83$ & $84-87$ & $88-91$ & $70-75$ & $76-79$ & $80-83$ & $84-87$ & $88-91$ & $84-87$ & $88-91$ \\
\hline $\begin{array}{l}\text { Industrial } \\
\text { Bank of } \\
\text { Japan }\end{array}$ & $60 \%$ & $54 \%$ & $61 \%$ & $44 \%$ & $47 \%$ & $79 \%$ & $89 \%$ & $91 \%$ & $95 \%$ & $75 \%$ & $100 \%$ & $100 \%$ \\
\hline $\begin{array}{l}\text { Dai-Ichi } \\
\text { Kangyo Bank }\end{array}$ & 70 & 83 & 100 & 95 & NA & 53 & 92 & 60 & 50 & 64 & 80 & 100 \\
\hline Sakura Bank & 95 & 97 & 98 & 100 & 100 & 97 & 50 & 49 & 75 & 67 & 100 & 100 \\
\hline $\begin{array}{l}\text { Mitsubishi } \\
\text { Bank }\end{array}$ & 72 & 80 & 73 & 100 & 100 & 98 & 100 & 99 & 93 & 75 & 100 & 100 \\
\hline Fuji Bank & 60 & 79 & 100 & 94 & 100 & 63 & 92 & 74 & 56 & 61 & NA & 100 \\
\hline $\begin{array}{l}\text { Sumitomo } \\
\text { Bank }\end{array}$ & 96 & 97 & 98 & 95 & NA & 91 & 76 & 83 & 85 & 94 & NA & 76 \\
\hline Sanwa Bank & 53 & 74 & 66 & 69 & NA & 60 & 94 & 80 & 37 & 53 & 100 & 100 \\
\hline
\end{tabular}

This table gives the answer to the question: Out of the trusteed bonds issued by a firm that has bank A as its main bank, what proportion (in amount) is trusteed (as the first trustee) by bank $A$ ? NA indicates the denominator is zero. 
Figure 1

Debt to Asset Ratio, Value-Weighted

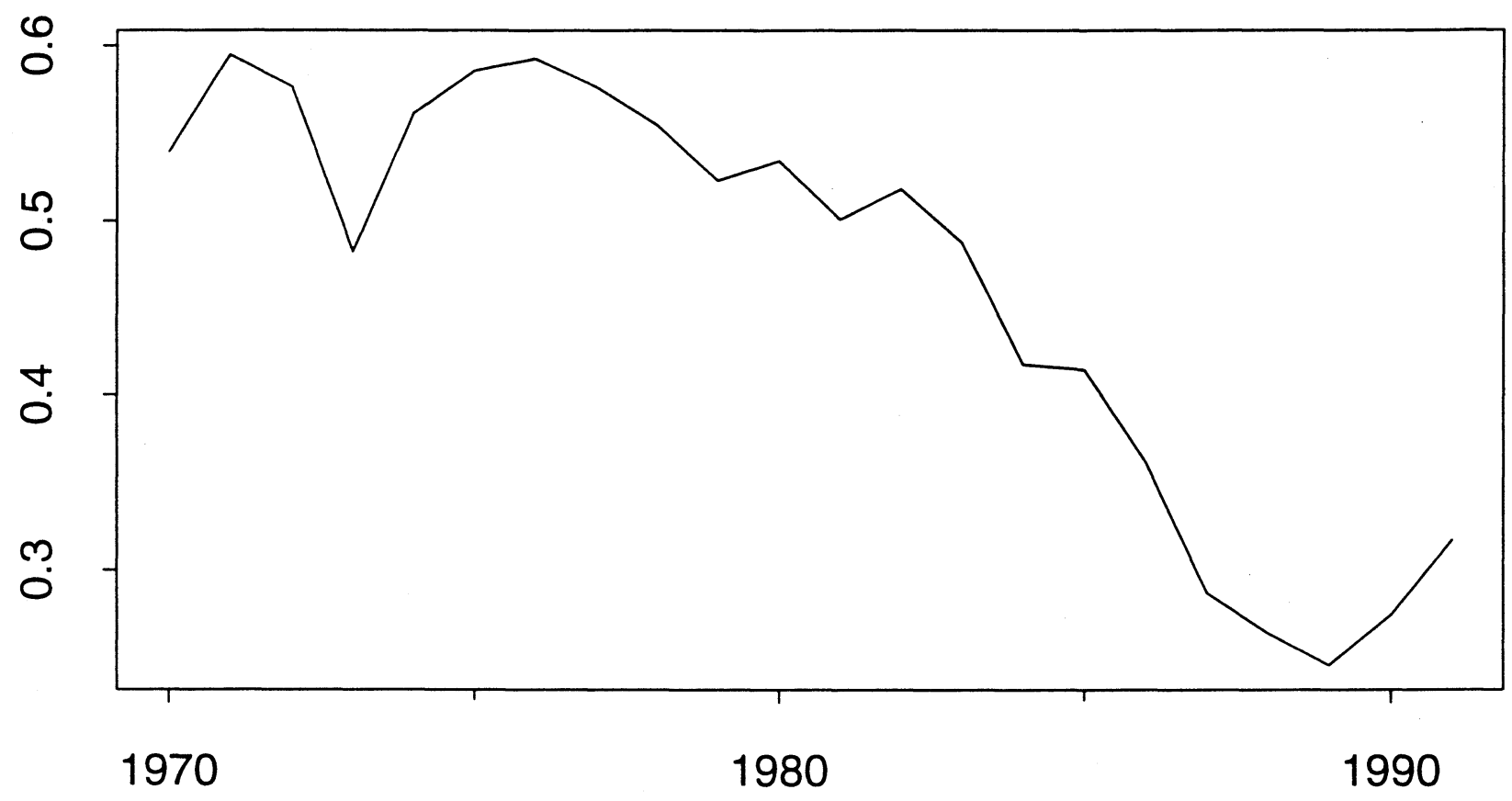


Figure 2

Debt to Asset Ratio, Firms with MB

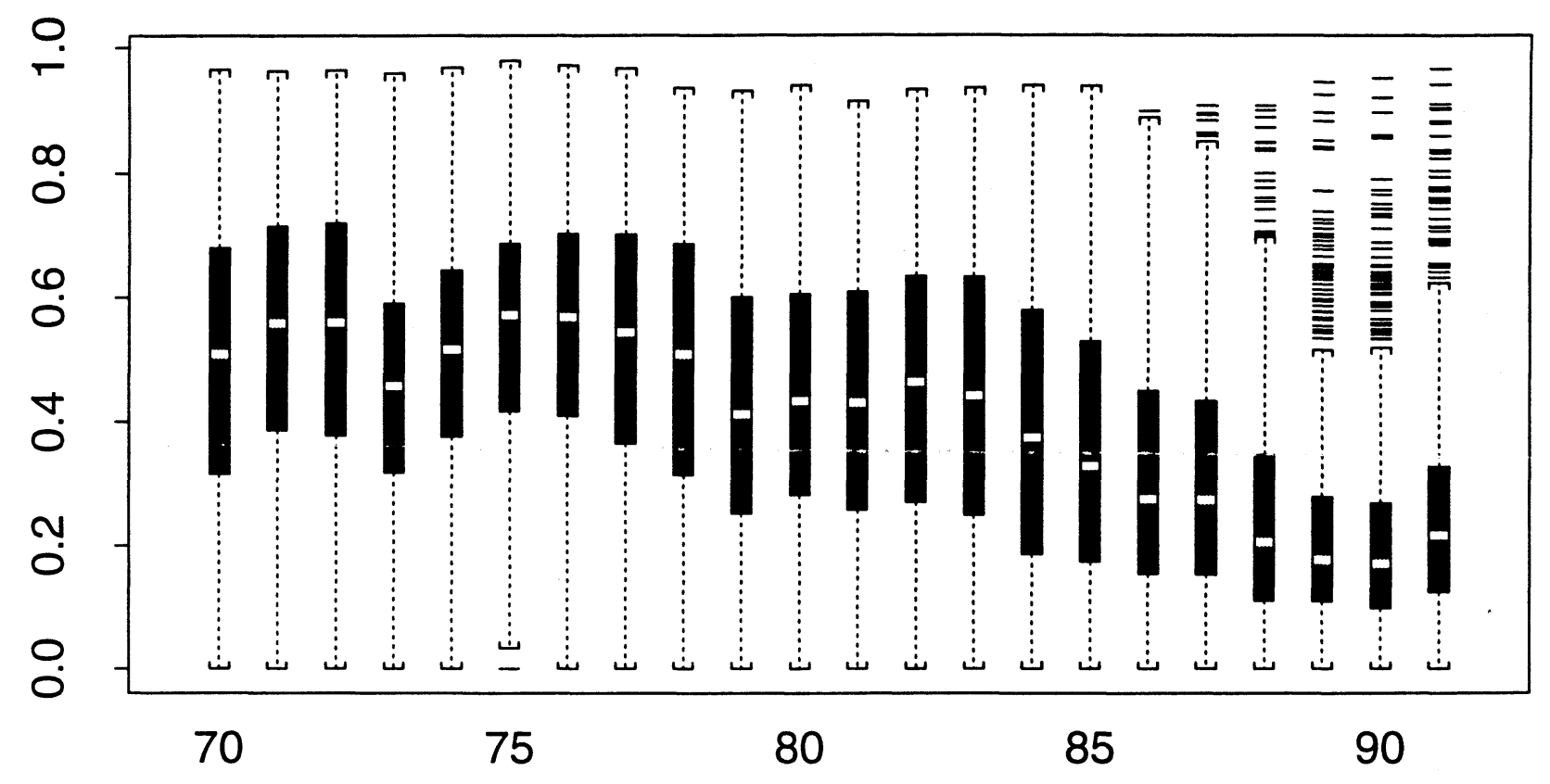

Debt to Asset Ratio, Firms w/o MB

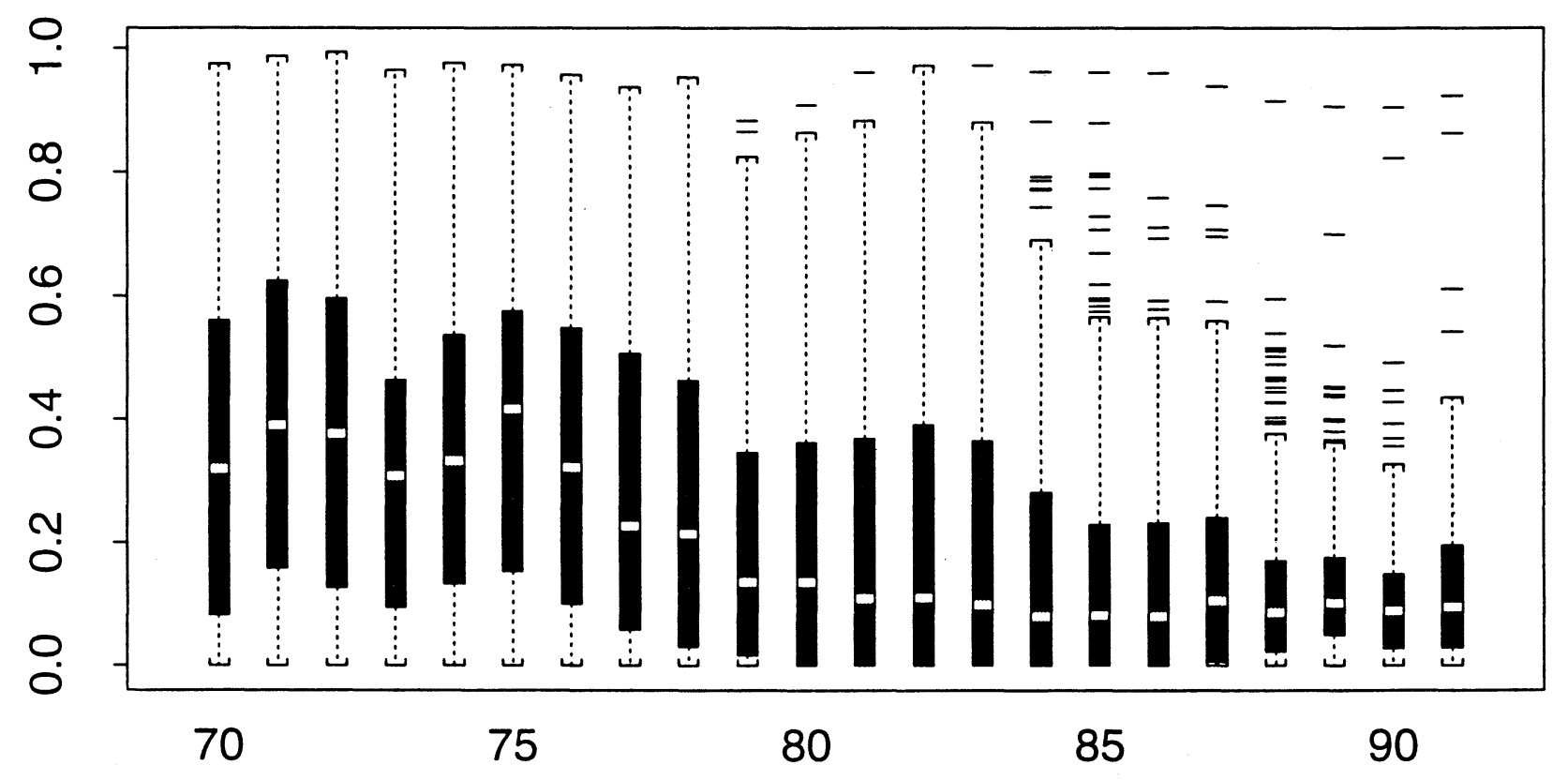


Figure 3

\section{Bond to Total Debt, Value-Weighted}

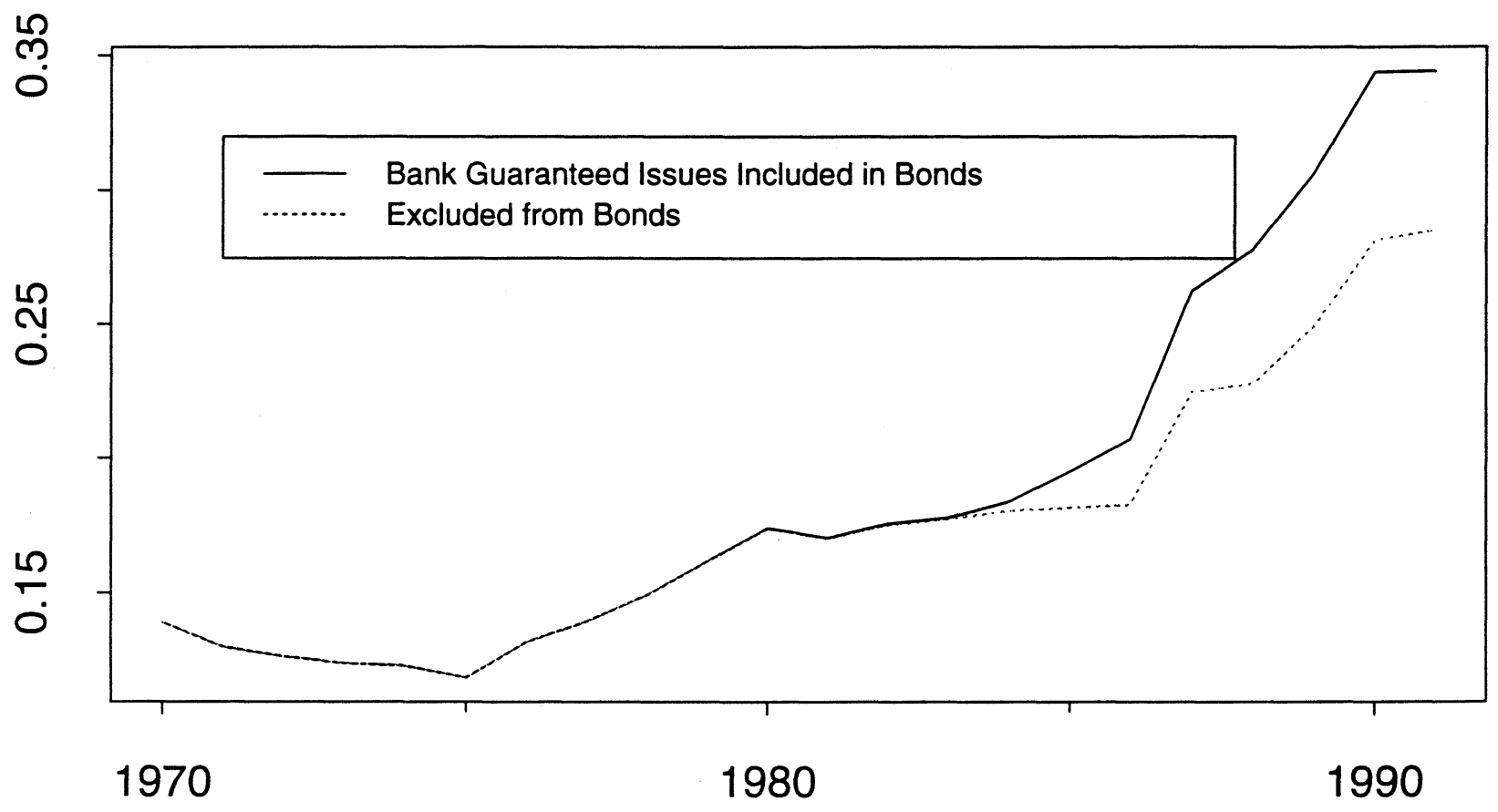


Figure 4-1

Bond to Total Debt Ratio, Firms with MB

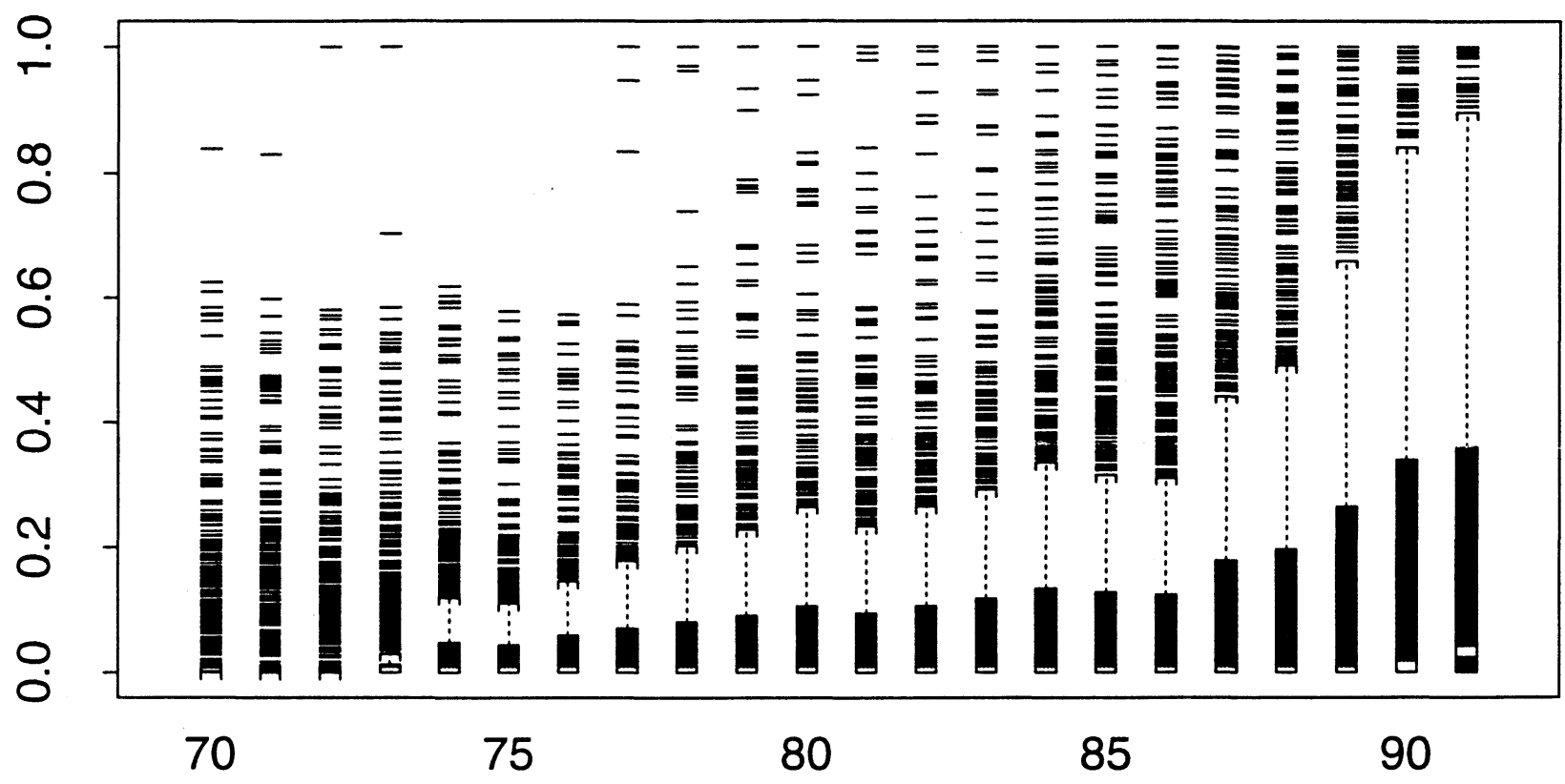

Bank Guaranteed Issues Excluded from Bonds

Bond to Total Debt Ratio, Firms w/o MB

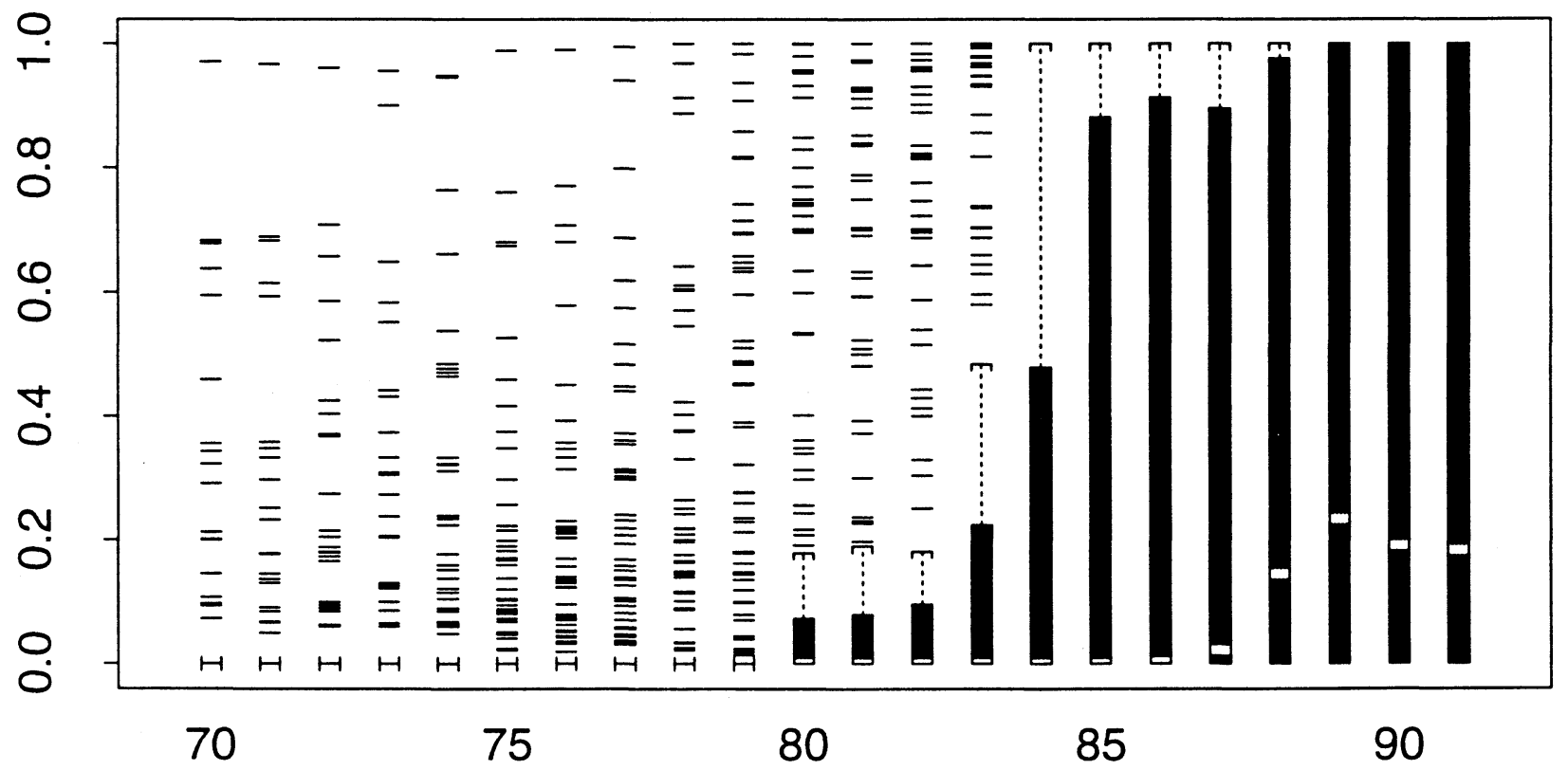


Figure 4-2

Bond to Total Debt Ratio, Firms with MB

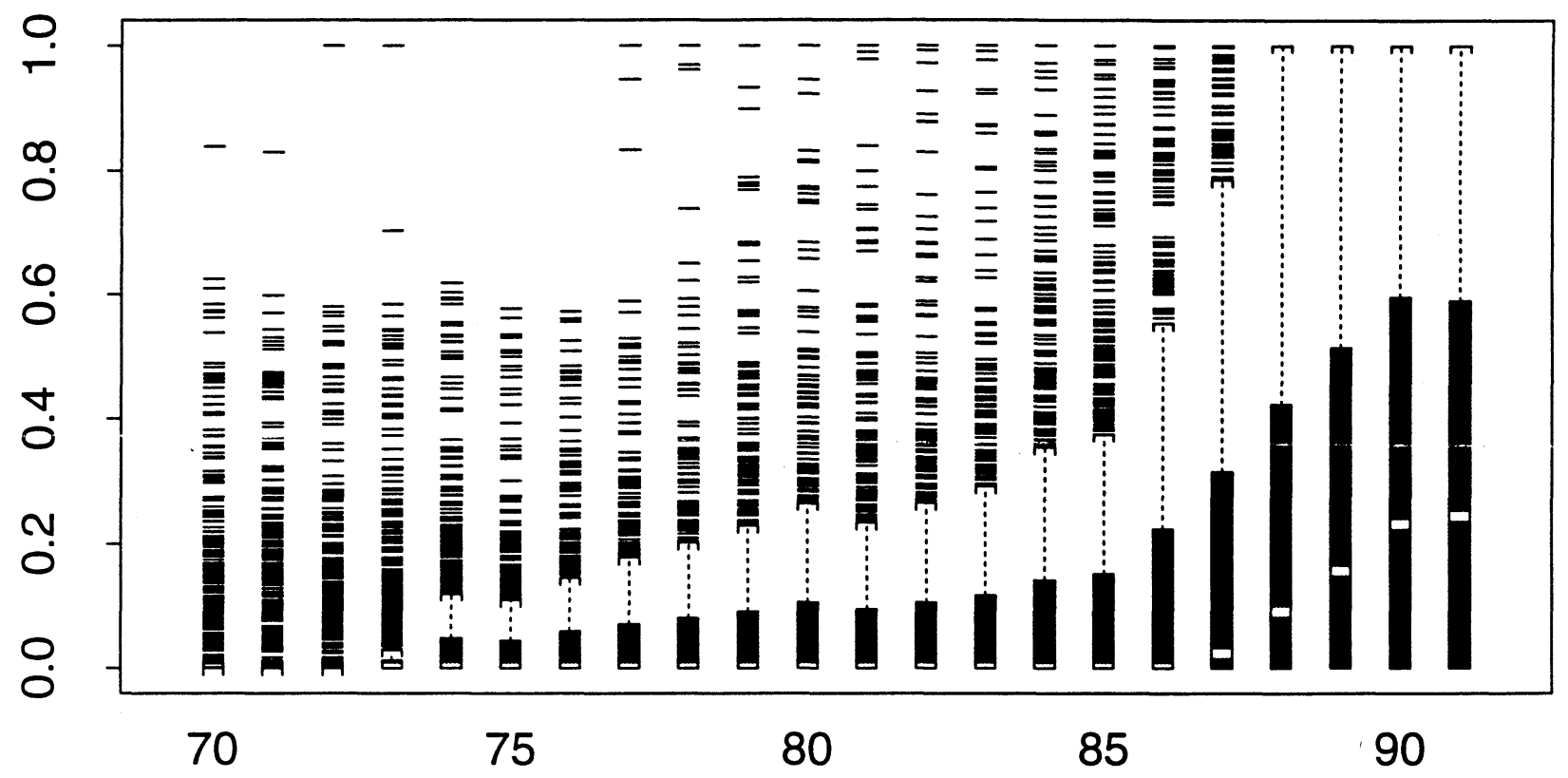

Bank Guaranteed Issues Included in Bonds

Bond to Total Debt Ratio, Firms w/o MB

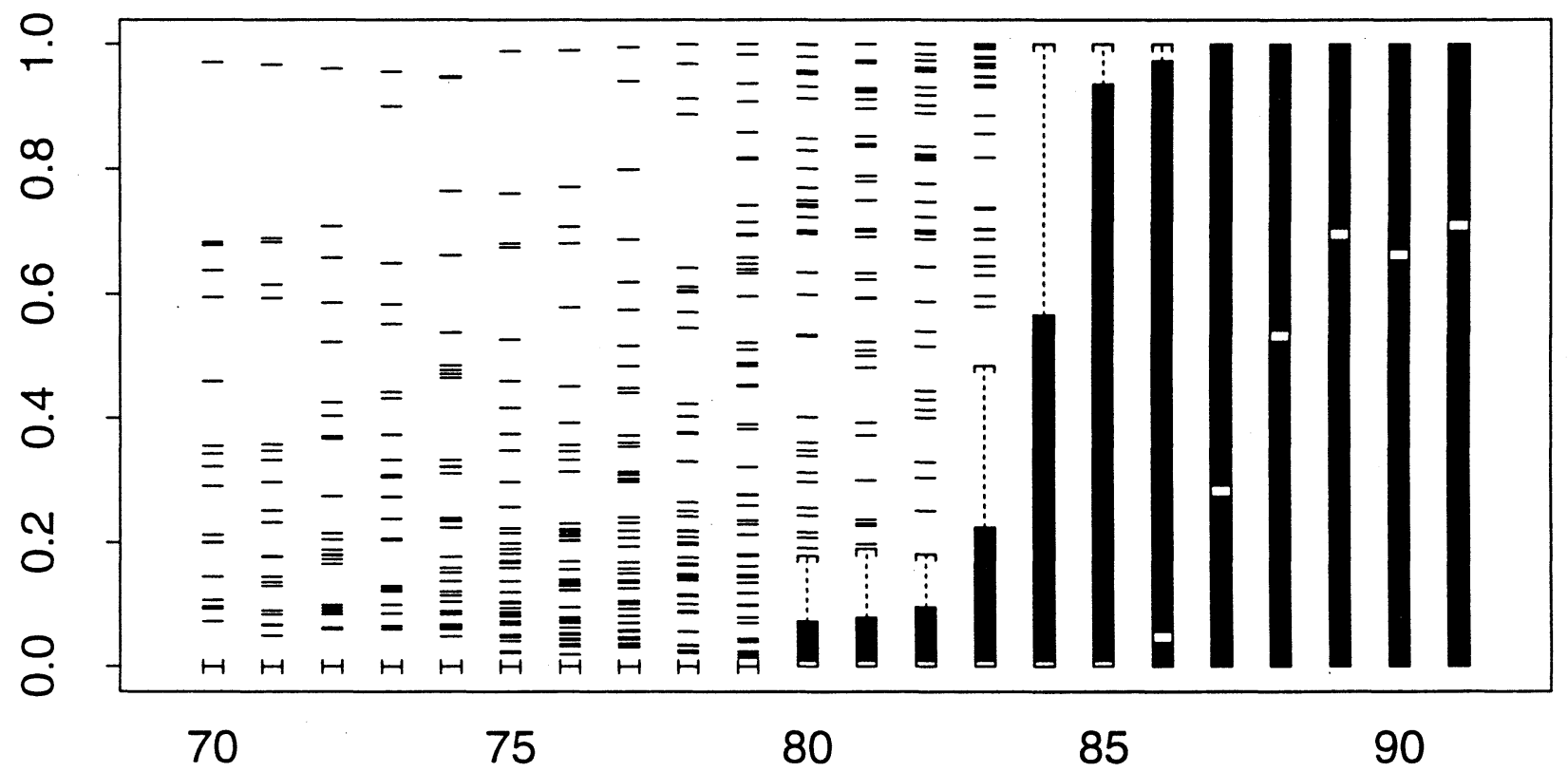


Figure 5

Short-Term Debt to Total Debt Ratio (VW)

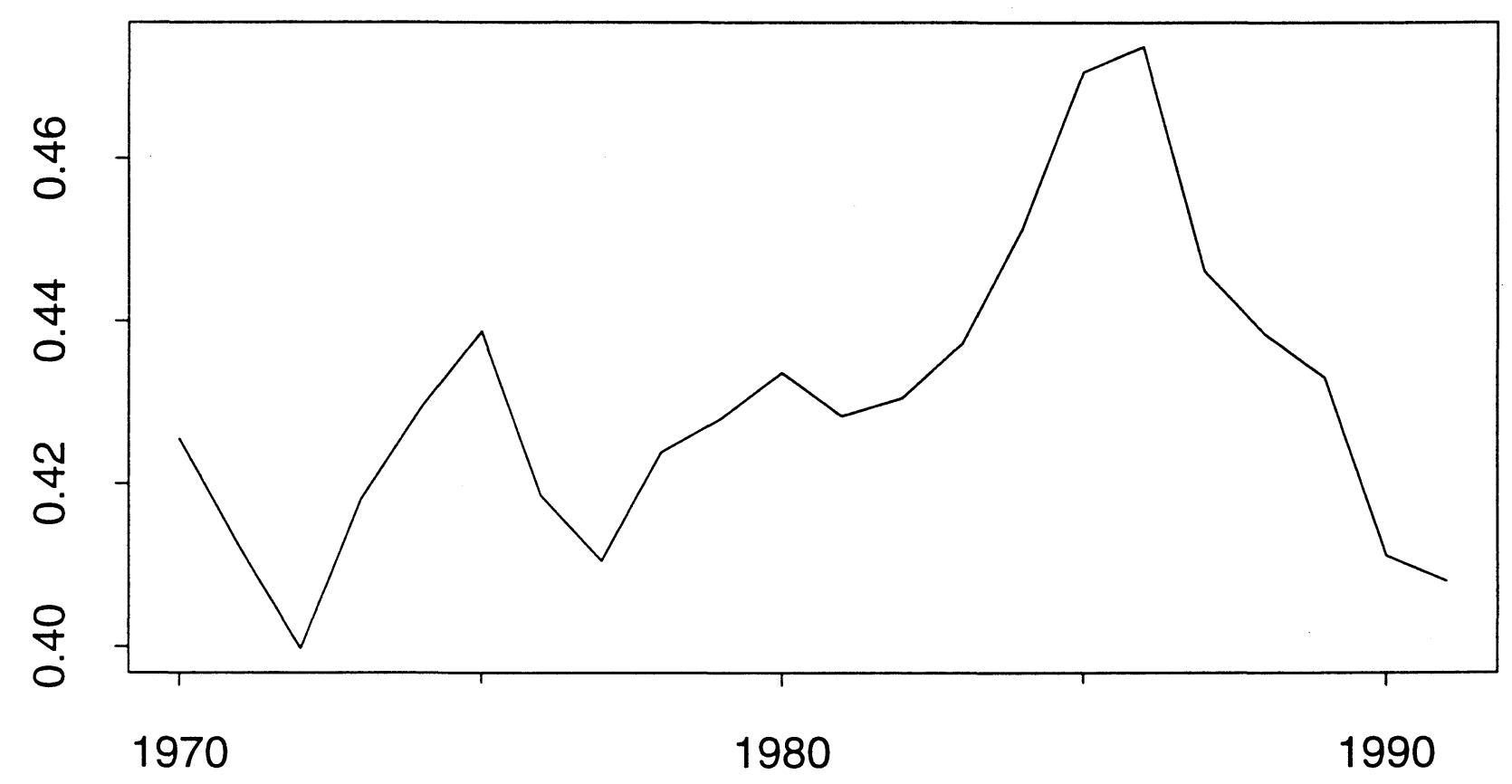


Figure 6

Short-Term Debt to Total Debt Ratio, Firms with MB

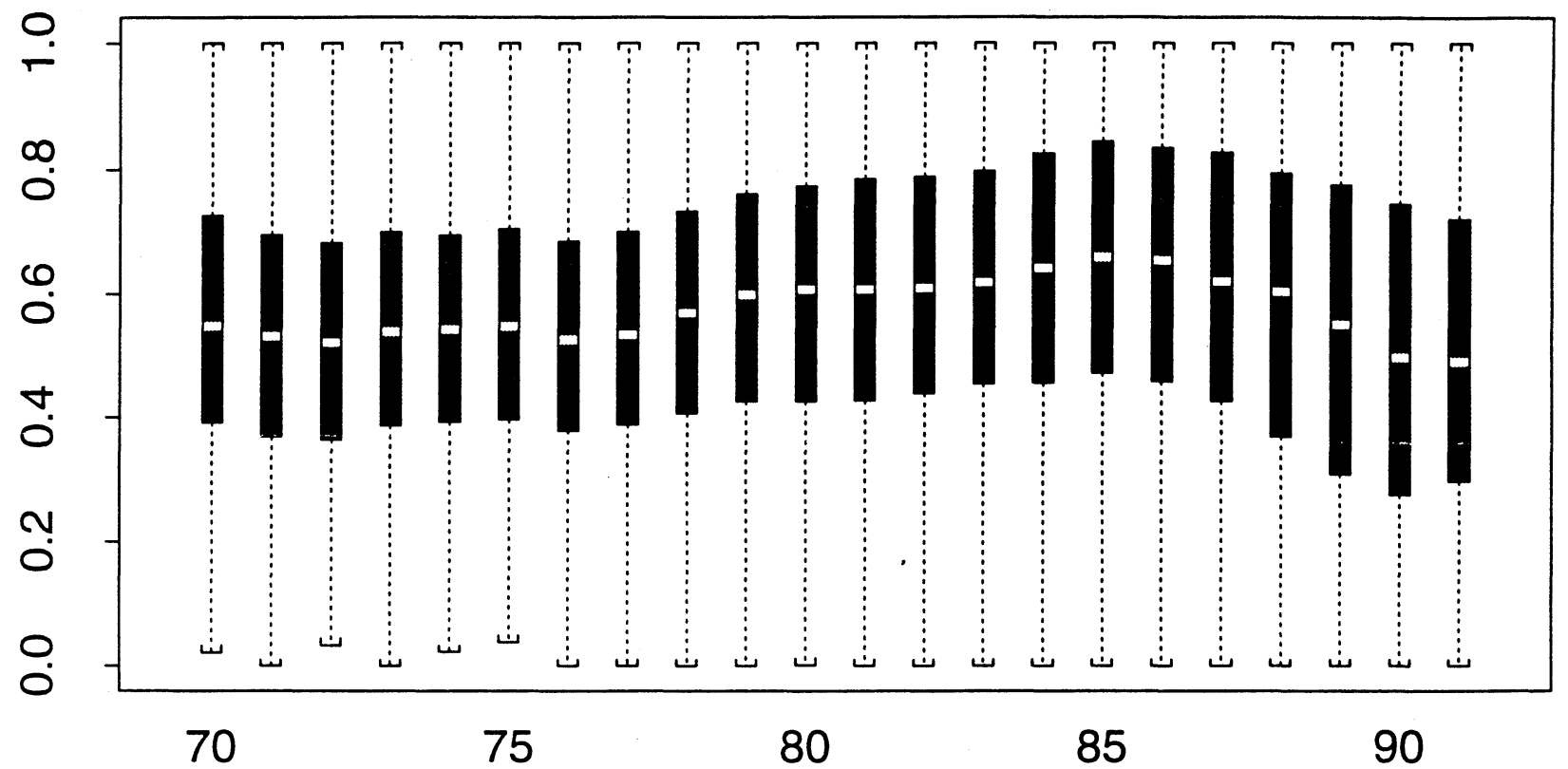

Short-Term Debt to Total Debt Ratio, Firms w/o MB

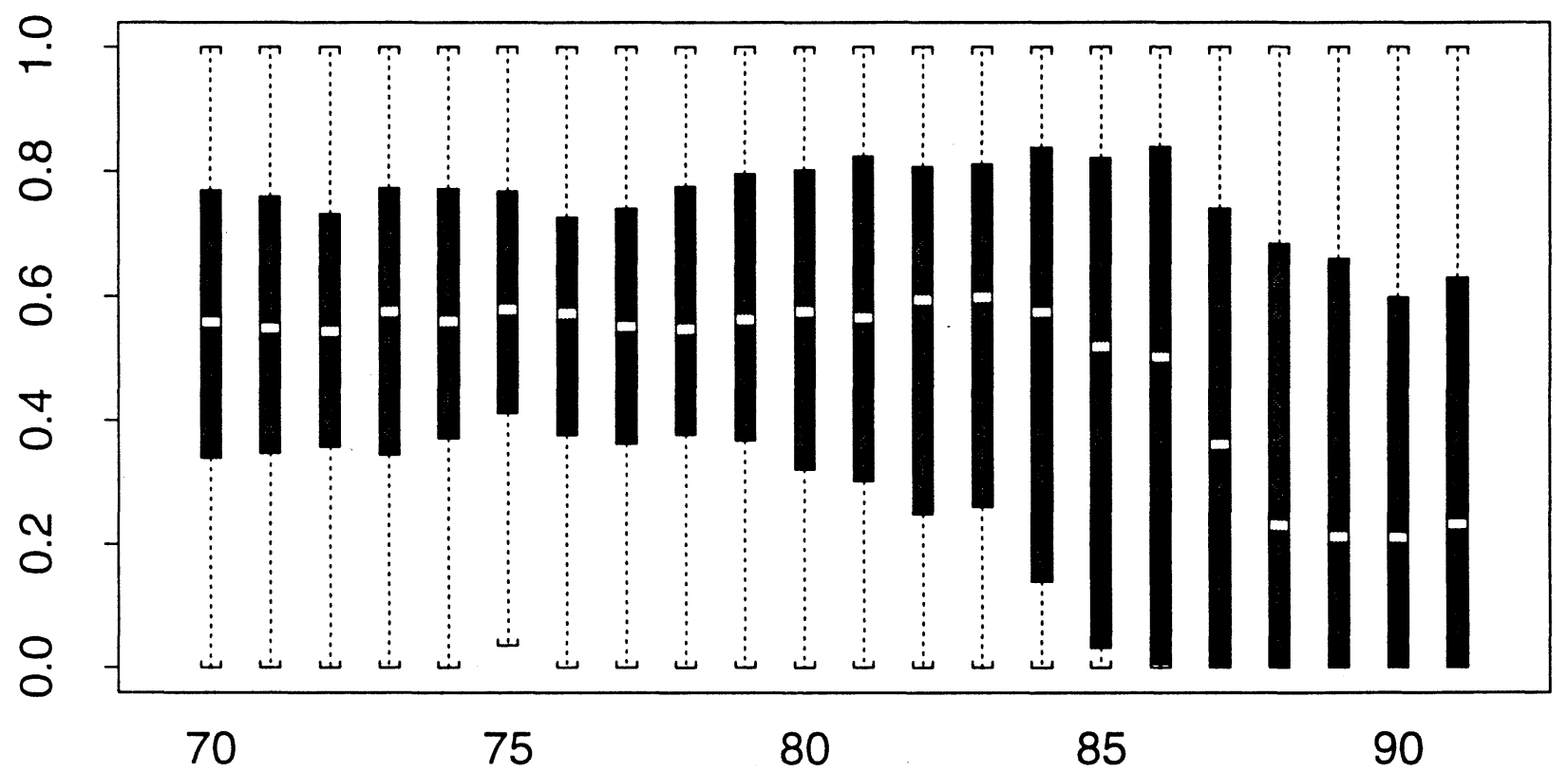


Figure 7

\section{Warrant Bond to Total Debt, Firms with MB}

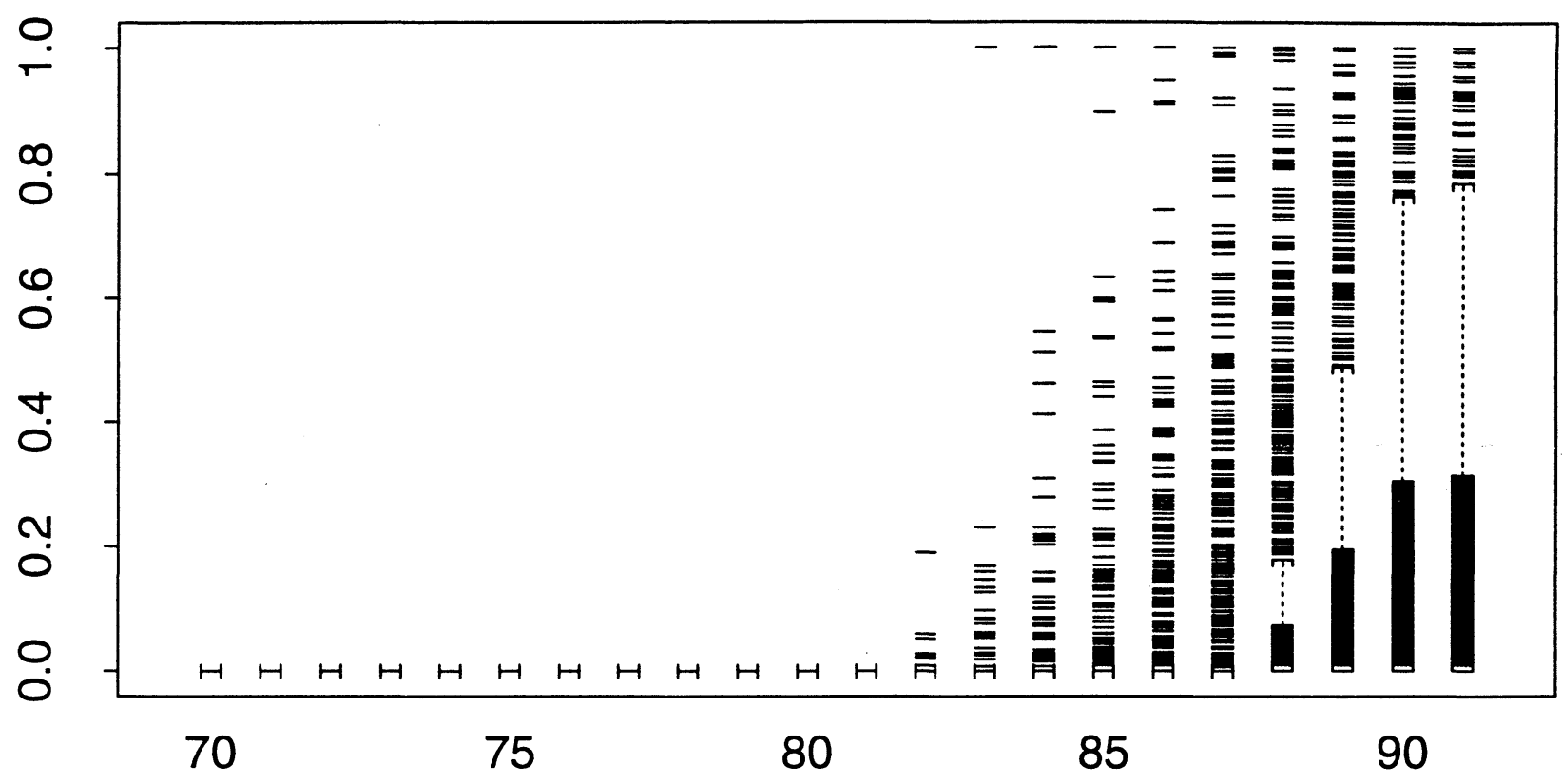

Warrant Bond to Total Debt, Firms w/o MB

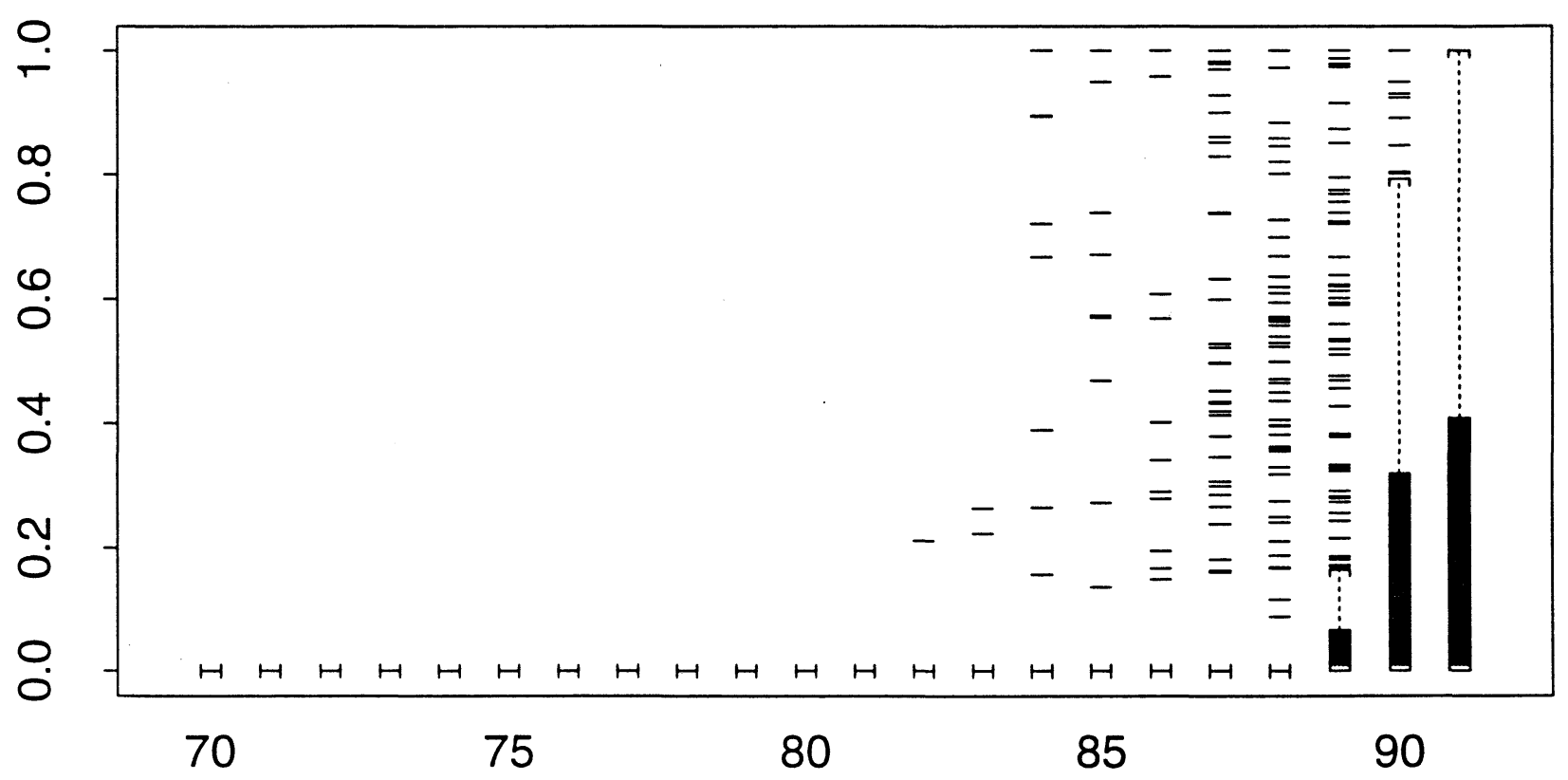


Figure 8

Convertible Bond to Total Debt, Firms with MB

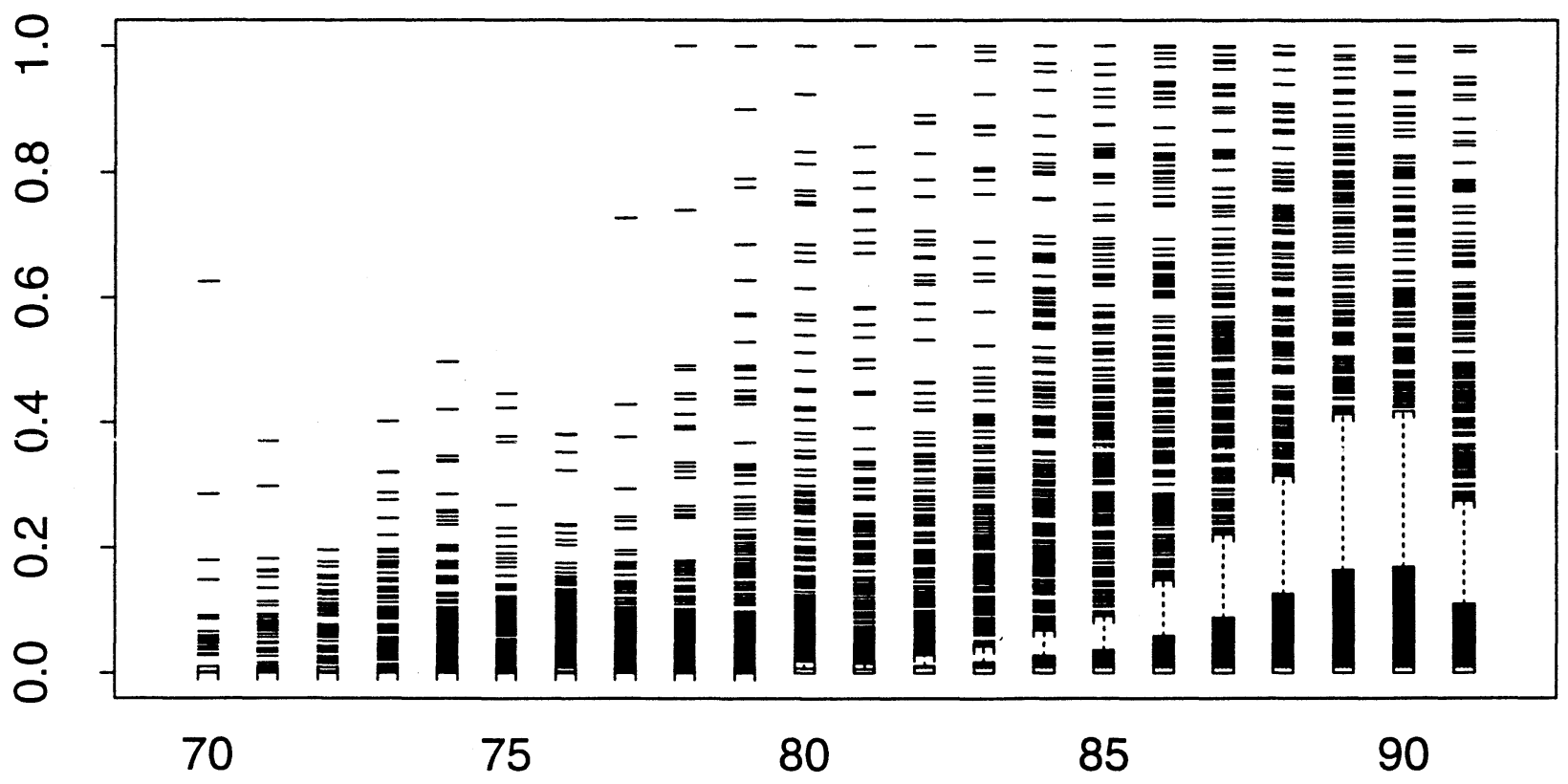

Convertible Bond to Total Debt, Firms w/o MB

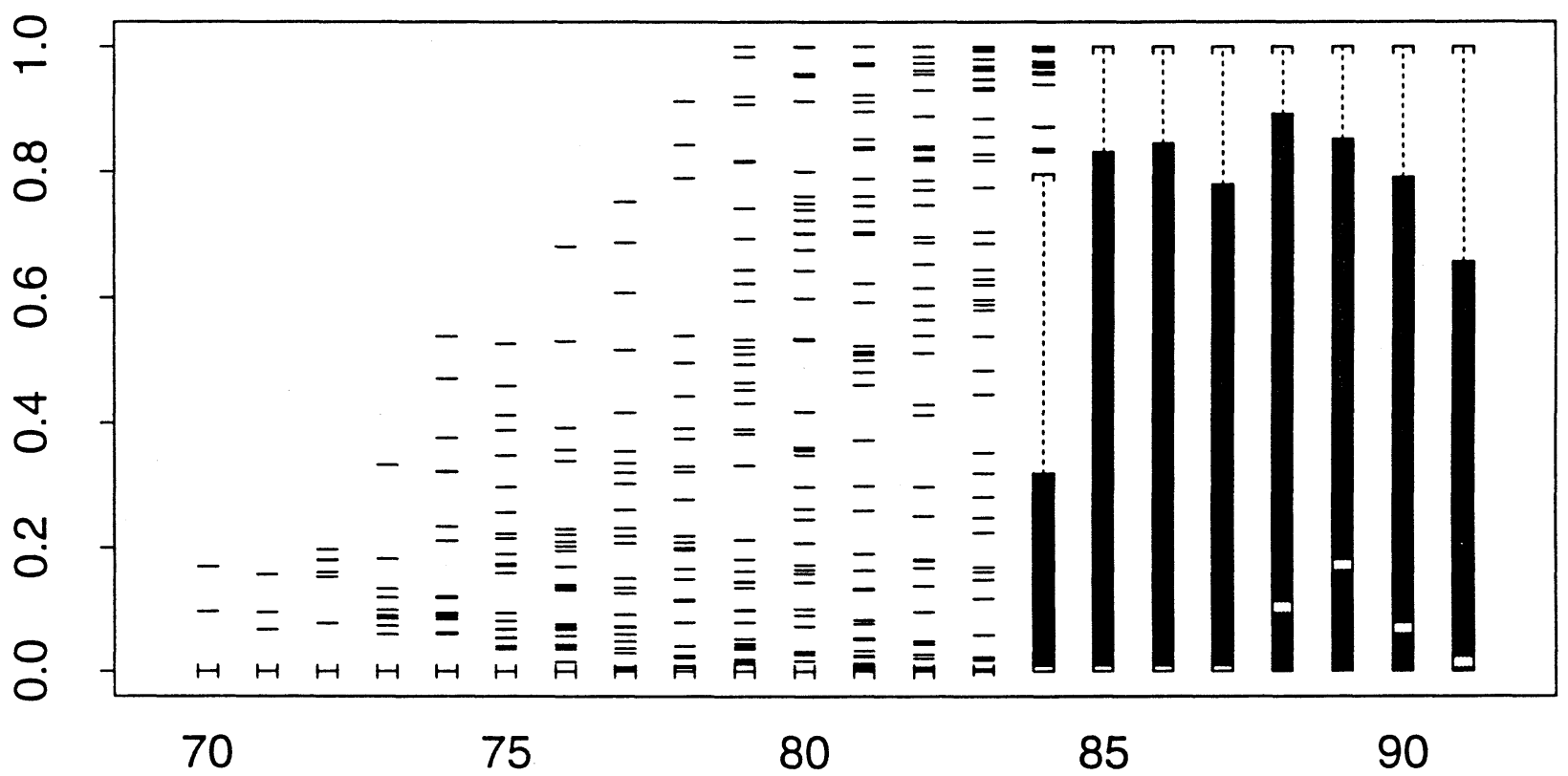

